\title{
Perspectives on Hypoxia Signaling in Tumor Stroma
}

\author{
Yuqing Zhang ${ }^{1,2,3} \mathbb{D}$, Morgan Coleman ${ }^{1,4}$ and Rolf A. Brekken 1,2,3,*(D) \\ 1 Hamon Center for Therapeutic Oncology Research, UT Southwestern, Dallas, TX 75390, USA; \\ yuqing.zhang@utsouthwestern.edu (Y.Z.); morgan.coleman@utsouthwestern.edu (M.C.) \\ 2 Department of Surgery, UT Southwestern, Dallas, TX 75390, USA \\ 3 Cancer Biology Graduate Program, UT Southwestern, Dallas, TX 75390, USA \\ 4 Division of Pediatric Hematology and Oncology, UT Southwestern, Dallas, TX 75390, USA \\ * Correspondence: rolf.brekken@utsouthwestern.edu; Tel.: +1-214-648-5151; Fax: +1-214-648-4940
}

check for

updates

Citation: Zhang, Y.; Coleman, M.; Brekken, R.A. Perspectives on Hypoxia Signaling in Tumor Stroma. Cancers 2021, 13, 3070. https:/ / doi.org/10.3390/cancers13123070

Academic Editor: Mark W Dewhirst

Received: 4 May 2021

Accepted: 17 June 2021

Published: 20 June 2021

Publisher's Note: MDPI stays neutral with regard to jurisdictional claims in published maps and institutional affiliations.

Copyright: (c) 2021 by the authors. Licensee MDPI, Basel, Switzerland. This article is an open access article distributed under the terms and conditions of the Creative Commons Attribution (CC BY) license (https:/ / creativecommons.org/licenses/by/ $4.0 /)$.
Simple Summary: Low oxygen tension (hypoxia) caused by high demand of cancer cell proliferation or standard of care therapy is a prevalent feature of solid tumors and is often associated with malignancy. The hypoxia-inducible transcription factor (HIF) family is the critical mediator driving the hypoxia signaling. HIF activity has diverse effects in tumor cells and on tumor stroma, including tumor vasculature, extracellular matrix, fibroblasts and immune cells. In this review, we focus on the effects of HIF in tumor stromal components and discuss essential functions of HIF regulating angiogenesis, collagen deposition and anti-tumor immunity. We also provide a brief overview of the current state of clinical studies targeting tumor hypoxia and provide insights on the limitation of hypoxia-targeted therapies. We believe, with comprehensive knowledge of hypoxia in the tumor microenvironment, challenges of hypoxia-targeted therapies might be better understood and addressed.

Abstract: Hypoxia is a well-known characteristic of solid tumors that contributes to tumor progression and metastasis. Oxygen deprivation due to high demand of proliferating cancer cells and standard of care therapies induce hypoxia. Hypoxia signaling, mainly mediated by the hypoxiainducible transcription factor (HIF) family, results in tumor cell migration, proliferation, metabolic changes, and resistance to therapy. Additionally, the hypoxic tumor microenvironment impacts multiple cellular and non-cellular compartments in the tumor stroma, including disordered tumor vasculature, homeostasis of ECM. Hypoxia also has a multifaceted and often contradictory influence on immune cell function, which contributes to an immunosuppressive environment. Here, we review the important function of HIF in tumor stromal components and summarize current clinical trials targeting hypoxia. We provide an overview of hypoxia signaling in tumor stroma that might help address some of the challenges associated with hypoxia-targeted therapies.

Keywords: hypoxia; HIF; tumor stroma; immune microenvironment

\section{Introduction}

Low oxygen tension (hypoxia) is prevalent in solid tumors and is associated with disease progression [1]. The growth of cancer cells often exceeds the capacity of the vasculature, and the resulting inadequacy of blood vessel function creates heterogeneous hypoxic areas within the tumor [2]. Hypoxic signaling and the downstream effects are mainly mediated by the hypoxia-inducible transcription factor (HIF) family, which consists of two subunits, HIF- $\alpha$ and HIF- $\beta$ (also known as the aryl hydrocarbon nuclear translocator, ARNT), of which HIF- $\beta$ is stably expressed [3]. There are three isoforms of HIF- $\alpha-\mathrm{HIF}-1 \alpha$, HIF- $2 \alpha$ and HIF- $3 \alpha$, with HIF- $1 \alpha$ and HIF- $2 \alpha$ having high similarity in structure and being widely studied [4]. HIF- $1 \alpha$ is expressed ubiquitously, while HIF- $2 \alpha$ and HIF- $3 \alpha$ have a more restricted expression pattern [5]. Under normoxic conditions, HIF- $\alpha$ subunits are hydroxylated at proline residues within oxygen-dependent degradation domain (ODD). 
This prolyl hydroxylation is mediated by prolyl hydroxylase domain-containing enzymes (PHDs) $[2,6]$. The hydroxylated proline residues (Pro-402/564 in human HIF- $\alpha$ ) within ODD domain can be recognized by the Von Hippel-Lindau (VHL) E3 ubiquitin ligase complex, thus mediating HIF- $\alpha$ ubiquitination and proteasomal degradation [6,7]. Under hypoxic conditions, the activity of PHDs is diminished due to lack of oxygen resulting in stabilized HIF- $\alpha$. Stabilized HIF- $\alpha$ binds to HIF- $\beta$ to form a heterodimer, which specifically binds hypoxia response elements that drive downstream target gene transcription and facilitate cellular adaptation to hypoxic conditions [8].

In addition to the oxygen deprivation caused by high metabolic demand of cancer cell proliferation, standard of care anticancer therapies can also induce or further exacerbate tumor hypoxia. For example, anti-angiogenic therapy has been reported to increase tumor aggressiveness or lead to therapy resistance in multiple models of cancer [9-11]. Antibodymediated inhibition of vascular endothelial growth factor (VEGF) has been shown to elevate hypoxia in pancreatic tumors and increase collagen deposition, which contributes to tumor aggressiveness [12]. Tyrosine kinase inhibitor BIBF 1120, which targets VEGF receptors, platelet-derived growth factor receptor, and fibroblast growth factor receptor, has also been reported to induce hypoxia in preclinical models of lung and pancreatic cancer [13]. Similar elevations in hypoxia were observed with sorafenib, a standard therapy for hepatocellular carcinoma [14]. In addition, bevacizumab (monoclonal antibody specific for VEGF) in combination with chemotherapy, the current standard of care therapy for metastatic colorectal cancer results in tumor hypoxia, which drives extracellular matrix (ECM) remodeling involved in acquired therapy resistance [15].

Hypoxia in tumors can induce abnormal angiogenesis and desmoplasia, and contribute to the immunosuppressive tumor microenvironment [3]. As a consequence, HIF- $1 \alpha$ and HIF- $2 \alpha$ expression have been reported to be associated with poor prognosis and metastasis of multiple human cancers [5]. Tumor cells have developed multiple advantages under hypoxic conditions, including increased cell proliferation and migration [16], metabolic changes [17], enhanced cancer cell stemness and resistance to radiotherapies and chemotherapies [18], which have been summarized in multiple reviews $[8,19,20]$. In addition to cancer cells, hypoxia impacts multiple features of the tumor microenvironment including tumor vasculature, ECM deposition and remodeling and other stromal cells, which may enhance immunosuppression and diminish the efficacy of immunotherapy (Figure 1) [2].

In this review, we will focus on the complex effects of hypoxia and HIF signaling on different cellular and non-cellular compartments in the tumor stroma, including tumor vasculature, ECM, and adaptive and innate immune cells. A current understanding of the hypoxic response of tumor stroma will be provided and current strategies in clinical trials to alleviate tumor hypoxia and the limitation of hypoxia targeted therapy will be discussed. 


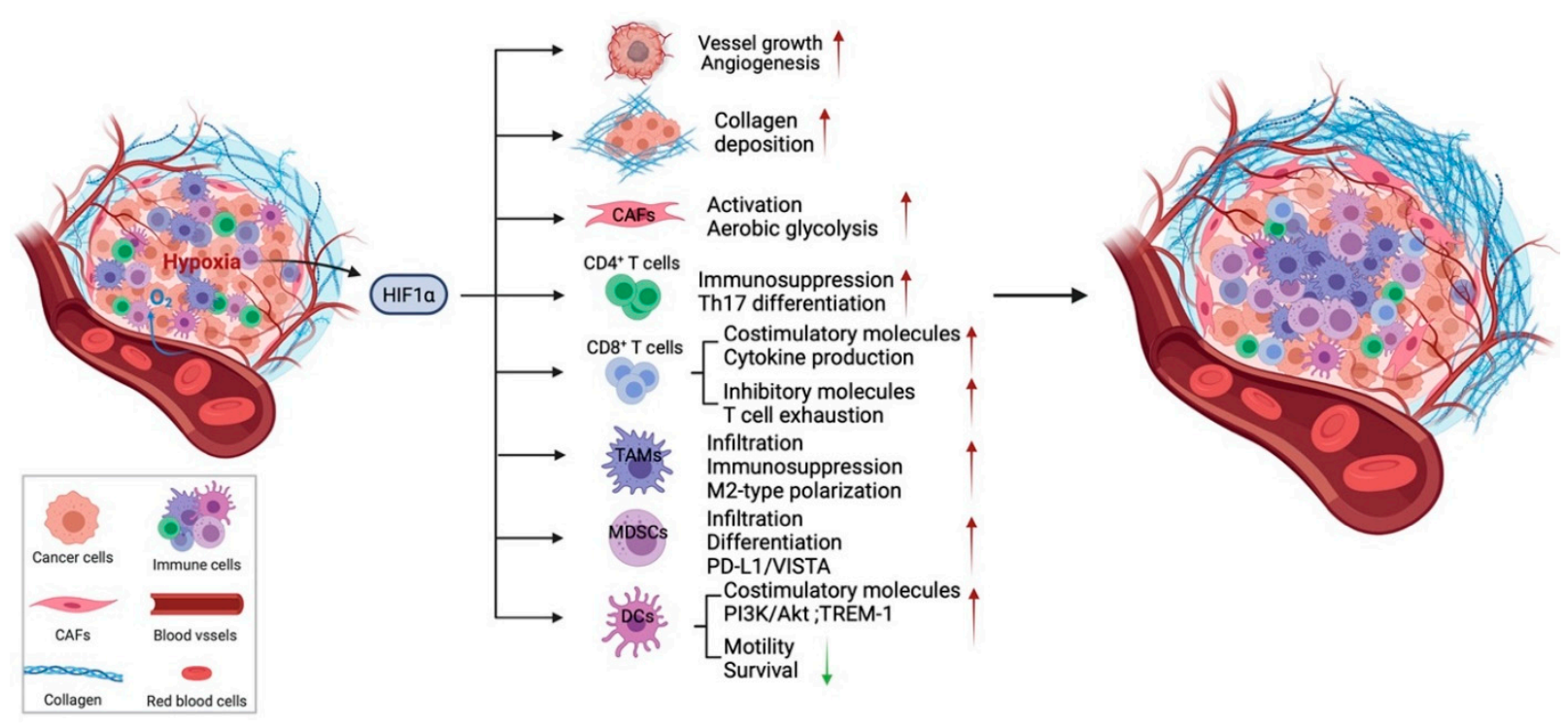

Figure 1. Hypoxia affects the tumor stroma. In addition to multiple effects of hypoxia on cancer cells, hypoxia through HIF- $1 \alpha$ signaling regulates the tumor stroma, including tumor vasculature, ECM, CAFs, and immune cells. HIF signaling is essential for vessel growth and maturation. Hypoxia also regulates CAF functions and leads to increased secretion of ECM components. However, the effects of hypoxia on each type of immune cell are complex and, in some cases, controversial. In general, hypoxia results in infiltration of immunosuppressive cells such as TAMs and Tregs and regulates the differentiation, phenotype polarization, as well as the cytotoxic function of immune cells to create an immunosuppressive environment. Hypoxia contributes to tumor progression, metastasis, and compromises the efficacy of standard of care therapy and immunotherapy in numbers of indications. Green arrow pointing down, decreased; red arrow pointing up, increased.

\section{Hypoxic Response of Tumor Vasculature}

The tumor vasculature is critical for oxygen and nutrient delivery to the cells that make up the tumor microenvironment. However, the tumor vasculature is often dysfunctional, leaky, irregular, and abnormal with aberrant pericytes, which lead to inefficient vessel perfusion [21]. In addition, rapid oxygen consumption in the tumor microenvironment contributes to stabilization of HIF and upregulation of proangiogenic factors such as VEGF secreted from cancer cells and stromal cells, which fuel disorganized new vessel formation [22]. The abnormal tumor vasculature in response to hypoxia can also limit drug delivery and enhance tumor progression and metastasis [22].

Accordingly, multiple studies have been conducted to determine the function of HIF$1 \alpha$ and HIF- $2 \alpha$ in endothelial cells. There is a universal switch from HIF- 1 to HIF-2 in endothelial cells during the response to hypoxia. HIF-1 activity is initiated in the acute phase of hypoxia while HIF-2 governs the adaptation to prolonged hypoxia [23]. Many factors have been identified that participate in this switch of HIF isoforms, including mRNA stability differences $[23,24]$. Loss of HIF- $1 \alpha$ in Tie $2^{+}$endothelial cells affects various parameters of endothelial cells, including proliferation, chemotaxis, and wound healing, and causes inhibition of tumor vessel density as well as reduction in tumor growth in a model of lung cancer (Lewis Lung carcinoma (LLC)) [25]. It has been demonstrated that hypoxia induces VEGF, VEGFR1, and VEGFR2 expression on endothelial cells while loss of HIF- $1 \alpha$ can block the induction of these genes, thus disrupting the hypoxia-induced VEGF autocrine loop [25]. Consistently, endothelial cell-specific deletion of HIF-1 $\alpha$ reduces lung metastasis in a genetic model of breast cancer, MMTV-PyMT, and leads to a reduction of circulating tumor cells in mice bearing LLC tumors [26]. Similarly, HIF-2 $\alpha$ deficiency in endothelial cells alters vascular function under physiological conditions and suppresses tumor angiogenesis associated with enhanced hypoxia and increases tumor cell apoptosis in LLC tumors [27]. In addition, in a skin carcinogenesis model, tumors with HIF-2 $\alpha$ deficient endothelial cells exhibit increased numbers of capillaries while reduced numbers of large vessels. However, these small vessels fail to mature into functional blood vessels 
and lead to perfusion defects, indicating an essential function of HIF- $2 \alpha$ in vessel sprouting and remodeling [28]. In summary, these studies indicate compensatory effects of HIF-1 $\alpha$ and HIF- $2 \alpha$ on tumor angiogenesis, with HIF- $1 \alpha$ contributing to vessel growth while HIF- $2 \alpha$ responsible for vessel maturation [29].

On the other hand, global heterozygous deficiency of PHD2, the oxygen sensor mediating HIF $\alpha$ subunit hydroxylation and degradation, results in reduced tumor intravasation and metastasis in B16 melanoma, Panc02 pancreatic cancer, and LLC models [30]. These effects were also found in a spontaneous genetic breast cancer model and found to be associated with improved vessel function and maturation [30,31]. These findings indicate the essential functions of HIF signaling in endothelial cells in regulating angiogenesis and highlight some of the potential challenges in targeting HIF activity as an anticancer strategy.

\section{Hypoxic Response of ECM and CAFs}

The extracellular matrix (ECM) is a dynamic collection of noncellular components within tissues including the tumor microenvironment. The ECM consists of collagens, fibronectin, laminin, and other proteoglycans and glycoproteins that contribute to tumor progression [32]. The ECM provides architectural support and tensile strength essential for tissue integrity [33]. In addition, ECM proteins bind to receptors on cancer cells or stromal cells to facilitate cell-ECM adhesion, which can regulate cancer cell proliferation, migration and metastasis [34]. Extensive ECM deposition is generally associated with malignancy of tumor progression as well as impaired drug delivery [35,36]. ECM is also a barrier for $\mathrm{T}$ cell infiltration which leads to tumors with a dense ECM typically being T cell-deficient [37]. Collagens, which are mainly produced by fibroblasts, are one of the major components of ECM [34]. Fibroblasts can be activated by cytokines such as TGF- $\beta$ in the tumor microenvironment and become cancer-associated fibroblasts (CAFs) that gain enhanced capacity to produce and remodel the ECM and are generally considered to promote cancer progression [38,39]. However, a recent study showed that genetic depletion of $\alpha$-smooth muscle actin ( $\alpha \mathrm{SMA})$-positive CAFs in pancreatic cancer model led to increased immunosuppression and accelerated tumor progression emphasizing the complexity of CAF biology [40,41]. Recently, evidence of CAFs heterogeneity with differential expression of specific markers in distinct subsets of CAFs has emerged, which may help dissect specific functions of CAFs subtypes in tumorigenesis [42-45].

Hypoxia regulates the homeostasis of ECM through HIF activity as several genes involved in collagen synthesis, modification, and degradation are targets of HIF [46,47]. For example, collagen prolyl 4-hydroxylases (P4Hs), essential enzymes in the synthesis of collagens and collagen lysyl hydroxylases (PLOD2) required for ECM stiffness, are induced in cancer cells by exposure to hypoxia, which is dependent on HIF- $1 \alpha$, but not HIF-2 $\alpha[48,49]$. Elevated expression of P4Hs and PLOD2 correlate with increased cancer cell adhesion to ECM and increased migration [50,51]. Knockdown of PLOD2 in pancreatic stellate cells limits the parallel-patterned fiber architecture formation and suppresses cancer cell directional migration in pancreatic cancer [52]. In non-small cell lung cancer (NSCLC) cell lines, HIF- $1 \alpha$ has been shown to form complex with mutant p53 resulting in the specific transcription of ECM genes [53]. Hypoxia has also been shown to elevate the rate of collagen synthesis and deposition in vitro and in vivo [46]. In addition, hypoxia has been shown to induce lysyl oxidase (LOX) and LOX-like proteins (LOXL) secretion by breast cancer cells. LOX and LOXL are amine oxidases that cross-link and stabilize collagen; these enzymes are implicated in remodeling the ECM in metastatic sites to promote metastasis niche formation. LOX/LOXL expression remodels ECM at metastatic sites to facilitate recruitment of bone marrow-derived cells, an effect dependent on HIF- $1 \alpha$ and HIF- $2 \alpha$ activity in tumor cells $[54,55]$. As a result, LOX inhibitors are being investigated as potential agents that might overcome chemoresistance and reduce metastasis in triple negative breast cancer [56].

However, the contribution of HIF- $1 \alpha$, and hypoxia by association, in CAFs is less clear. There is evidence that HIF- $1 \alpha$ activity in CAFs can function as a tumor promoter. For 
example, a human fibroblast cell line with active HIF-1 $\alpha$ promotes MDA-MB-231 tumor growth when co-injected in vivo with tumor cells. This phenotype is associated with decreased mitochondrial activity and a shift toward aerobic glycolysis [57]. A recent study has confirmed the shift toward lactate and pyruvate production in CAFs isolated from breast cancer patients compared to normal fibroblasts is due to epigenetic reprogramming of HIF- $1 \alpha$ and glycolytic enzymes [58]. Chronic hypoxia induces hypomethylation of HIF1A promoter as well as promoters of rate-limiting glycolytic genes PKM and LDHA, which lead to elevated transcript and protein levels and contribute to enhanced glycolytic activity of CAFs derived from breast cancer patients [58]. Furthermore, hypoxic mammary CAFs derived from triple-negative breast cancer patients promote angiogenesis and abnormal vessel formation in a CAF-endothelial cell co-culture system [59]. On the contrary, loss of HIF- $1 \alpha$ specifically in $\mathrm{FSP}^{+}$CAFs was found to accelerate mammary tumor growth and also contribute to decreased tumor vessel density [60]. In addition, global PHD2 haplodeficiency was reported to decrease CAF activation and impair CAF migration and ECM deposition, which reduced metastasis in a spontaneous MMTV-PyMT breast cancer model [31]. Interestingly, the effect on CAF activity relies on PHD2 deletion on tumor cells, but not on CAFs as PHD2 deficiency in platelet-derived growth factor receptor $\alpha$ (PDGFR $\alpha$ )-positive CAFs does not influence metastasis [31]. However, another study provided evidence that depletion of PHD2 in human head and neck CAFs phenocopies the response to hypoxia in a 3D collagen I/Matrigel culture system [61]. Furthermore, a pan-PHD inhibitor (DMOG) reduces tumor stiffness and metastasis in mice bearing $4 \mathrm{~T} 1$ breast cancer. Interestingly, this efficacy appears to be achieved by targeting PHD2 in CAFs [61]. These contradictory results highlight the complexity and heterogeneity of CAF biology.

In general, the hypoxic tumor microenvironment directly effects collagen deposition and ECM remodeling mainly through HIF activity, which typically enhances tumor progression and metastasis. However, the functions of HIF- $1 \alpha$ and HIF signaling in CAFs are more complicated given the heterogeneity of CAF subpopulations, which likely contributes to the seemingly contradictory findings regarding CAF biology and hypoxia.

\section{The Effect of Hypoxia on T Cells}

Hypoxia has direct and complex effects on tumor-infiltrating $\mathrm{T}$ cells, including different subtypes of $\mathrm{CD} 4^{+} \mathrm{T}$ helper cells and $\mathrm{CD} 8^{+}$effector $\mathrm{T}$ cells, potentially resulting in reduced efficacy of immunotherapies.

\section{1. $C D 4^{+} T$ Helper Cells and Regulatory $T$ Cells}

There are several subtypes of $\mathrm{CD} 4^{+} \mathrm{T}$ cells, due to divergent differentiation of naïve progenitor cells in response to different cytokine stimuli. The most commonly studied CD4 ${ }^{+}$ $\mathrm{T}$ cells in the immune response to cancer are $\mathrm{T}$ helper $(\mathrm{Th}) 1$, Th2, Th17, and regulatory $\mathrm{T}$ cell (Treg) [62]. Th1 cells characterized by secreting stimulatory cytokines IFN- $\gamma$ and TNF- $\alpha$ are considered as proinflammatory and they prime $C D 8^{+} \mathrm{T}$ cells and are responsible for driving an immune response against tumor cells or infection [63]. While Th2 and Th17 cells may promote tumor growth through expression of immunosuppressive cytokines including IL-4, IL-5, IL-13, and IL-17A, although the contribution of these cells to the tumor immune landscape is not completely clear $[62,64-68]$. CD4 ${ }^{+}$Tregs are characterized by transcription factor FoxP3 expression and are predominantly immunosuppressive. Tregs maintain peripheral tolerance under normal conditions. The recruitment and expansion of Tregs is enhanced in most tumors and typically impedes antitumor activity of effector cells [69].

Continuous stimulation of the T cell receptor (TCR) under normoxic conditions induces HIF- $1 \alpha$ expression through PI3K/mTOR signaling [70,71]. However, hypoxia in tumors can elevate HIF- $1 \alpha$ expression in T cells, which contributes to immunosuppression and the differentiation of $\mathrm{CD}^{+} \mathrm{T}$ cells. Th1 cells cultured under hypoxia downregulate Th1 responses of IFN- $\gamma$ production and demonstrate active phosphorylation of STAT3 which 
leads to further enhanced HIF-1 $\alpha$ transcription [72]. In ovarian cancer cells, expression of the chemokine CC-chemokine ligand 28 (CCL28) was reported to be upregulated by hypoxia and correlated with HIF-1 $\alpha$ expression. CCL28 promotes tumor growth through the recruitment of CCR10 ${ }^{+}$Tregs [73]. In addition, HIF- $1 \alpha$ directly influences the balance between the differentiation of Tregs and Th17 cells by promoting Th17 development while attenuating Treg differentiation through binding FoxP3 resulting in proteasomal degradation [74]. An insertional mutation of FoxP3 that interferes with HIF- $1 \alpha$ binding increases FoxP3 stability and Treg differentiation [75]. HIF-1 $\alpha$ also contributes to T cell metabolism and thereby promotes lineage choices towards Th17 cells rather than Tregs by favoring glycolytic pathways that are highly active in Th17 cell-inducing conditions [76]. Consistently, another study illustrated the detrimental function of HIF- $1 \alpha$ on Treg differentiation by showing that Tregs deficient in VHL, the E3 ubiquitin ligase mediating HIF- $1 \alpha$ ubiquitination, lose their suppressive function to control inflammation but produce massive IFN- $\gamma$ and are converted to Th1-like effector T cells [77]. However, the exact effect of HIF- $1 \alpha$ on the differentiation and activity of Tregs remains controversial. Studies have also demonstrated that HIF- $1 \alpha$ can promote FoxP3 expression and abundance as well as the suppressive activity of Tregs [78-80]. Treg-intrinsic HIF-1 $\alpha$ is indispensable for optimal Treg function and Tregs deficient in HIF- $1 \alpha$ fail to control inflammation [79]. In addition to studies on HIF- $1 \alpha$, a recent study has demonstrated a critical function of HIF- $2 \alpha$ in regulating Treg activity [81]. When HIF-2 $\alpha$ was specifically knocked out in Tregs, the cells lost their ability to inhibit effector $\mathrm{T}$ cell induced inflammation, which is due in part to upregulated HIF- $1 \alpha$. In tumor settings, HIF- $2 \alpha-\mathrm{KO}$ Tregs contribute to suppression of MC38 tumor growth and B16F10 melanoma metastasis [81].

Hypoxia is known to stimulate cytokine and chemokine secretion from cancer cells and tumor-infiltrating myeloid cells that recruit Treg infiltration. However, more studies are needed to address the controversial evidence of HIF signaling in determining the differentiation of Tregs and Th17 cells and their subsequent functions.

\section{2. $C D 8^{+}$Effector T Cells}

$\mathrm{CD}^{+}$effector $\mathrm{T}$ cells are the main cytotoxic cell type mediating antitumor immune responses. After antigen-presentation and appropriate co-stimulation from antigen-presenting cells (APCs), $\mathrm{CD} 8^{+} \mathrm{T}$ cells undergo clonal expansion and migration into tumor sites, where they recognize tumor-specific antigens and initiate cytotoxic effects by releasing perforin, granzyme to induce tumor cell apoptosis [82]. The canonical tumor antigen recognition is mainly mediated by $\alpha \beta C D 8^{+} \mathrm{T}$ cells, while there is another distinct population $\gamma \delta$ $\mathrm{CD}^{+}$cells recognizing lipid antigens in an antigen presentation-independent manner [83]. During trafficking into the tumor microenvironment, $\mathrm{CD} 8^{+} \mathrm{T}$ cells encounter a low oxygen tension [84], which can influence their phenotype and activity.

Studies have provided evidence of stimulatory and inhibitory effects of hypoxia on $\alpha \beta$ $\mathrm{CD}^{+} \mathrm{T}$ cells. Hypoxia can enhance the expression of CD137, a member of the TNF receptor family that functions as costimulatory molecule on activated $\mathrm{T}$ cells and is present on tumorinfiltrating lymphocytes (TILs) in multiple implanted and spontaneous tumor models. In HIF- $1 \alpha$-knockout T cells, CD137 expression does not respond to hypoxia and remains negative on those T cells [85]. Furthermore, T lymphocytes that develop under hypoxic conditions are more sustained and lytic with elevated expression of activation markers and enhanced cytokine production [86,87]. Consistently, a later study has demonstrated that enhanced HIF activity by deleting VHL on $\mathrm{CD}^{+} \mathrm{T}$ cells increases granzyme $\mathrm{B}$, perforin, and TNF production as well as expression of costimulatory molecules, thus sustaining effector functions that are critical for clearance of viral infection and tumors [84]. Hypoxic cytotoxic $\mathrm{T}$ lymphocytes when transferred in vivo were reported to package more granzyme $\mathrm{B}$ and be more efficient in controlling tumor growth and improve animal survival in a B16-OVA tumor model [88]. However, loss of HIF- $1 \alpha$ but not HIF- $2 \alpha$ in CD8 ${ }^{+} \mathrm{T}$ cells accelerates tumorigenesis [89]. Deletion of HIF- $1 \alpha$ or one of it targets, VEGF-A specifically in $\mathrm{CD}^{+} \mathrm{T}$ cells limits $\mathrm{T}$ cells migration and infiltration into tumor sites in LLC and B16-F10 
subcutaneous models [89]. Furthermore, the response of MC38 tumors to anti-PD-1 and anti-CTLA-4 combinational immunotherapy is compromised in mice with HIF- $1 \alpha$ loss in $\mathrm{CD}^{+} \mathrm{T}$ cells [89]. HIF-1 regulated by mTORC1 is required for glucose metabolism in effector $\mathrm{T}$ cells and controls expression of chemokines and adhesion molecules regulating $\mathrm{T}$ cell migration [90]. In contrast, hypoxia has also been reported to suppress $\mathrm{CD}^{+} \mathrm{T}$ cells. Hypoxia is known to decrease proinflammatory cytokine production from cytotoxic $\mathrm{T}$ cells such as IL-2 and IFN- $\gamma$ and delay T cell development in physiologic oxygen level culture condition [91], which has been shown to be mediated by HIF-1 $\alpha$ by specific deletion of HIF-1 $\alpha$ in T cells [92]. Hypoxia also increases expression of inhibitory molecules and promotes $\mathrm{T}$ cell exhaustion by inducing mitochondrial defects $[84,93]$. In addition, hypoxia caused by tumor deregulated oxidative metabolism is associated with decreased $\mathrm{T}$ cell activity and response to anti-PD-1 therapy [94]. These contradictory results indicate that there might be a balance of HIF- $1 \alpha$ activity and the function of cytotoxic T cells in the tumor microenvironment and highlight that these issues are ripe for additional investigation.

\section{The Effect of Hypoxia on Myeloid Cells}

\subsection{Tumor-Associated Macrophages}

As a major component in the tumor microenvironment, tumor-associated macrophages (TAMs) are generally considered as immunosuppressive cells that promote tumor progression, metastasis and angiogenesis [95]. In response to different stimuli in the tumor microenvironment, macrophages are known to exist on a spectrum of phenotypes ranging from immunostimulatory to immunosuppressive. Th1 cell-associated cytokines or LPS stimulation can polarize macrophages into a proinflammatory phenotype (M1-like macrophages), while IL-4 or IL-13 from Th2 cells stimulate an immunosuppressive phenotype (M2-like macrophages) [96,97]. Tumor hypoxia is critical in determining the phenotype of macrophages and hypoxic TAMs have been shown to release factors facilitating tumor growth and immunosuppression [98]. In addition, hypoxia influences the spatial arrangement of macrophages. In more hypoxic regions of a tumor, TAMs tend to be M2-like type while M1-like macrophages are more commonly found in normoxic regions, typically in the periphery of a tumor $[98,99]$. HIF- $1 \alpha$ contributes to the recruitment of bone marrow-derived $\mathrm{CD} 45^{+}$myeloid cells including macrophages and further regulates tumor angiogenesis and invasion indirectly [100]. The infiltration of TAMs to hypoxic tumor areas is due to various stimuli including Sema3A/Nrp1 signaling, VEGF, migratory stimulating factors such as colony-stimulating factor 1 (CSF1), CCL2, CCL5 as well as upregulation of TGF $\beta$ and M-CSFR [101-103]. In addition, a subset of M2-like TAMs $\left(\mathrm{MRC} 1^{+} \mathrm{TIE}^{\mathrm{Hi}}{ }^{\mathrm{CXCR}} 4^{\mathrm{Hi}}\right.$ ) were identified to accumulate around tumor vasculature in breast and lung tumors after chemotherapy, which contributed to tumor relapse after therapy [104].

TAMs in hypoxic regions of tumor tend to be immunosuppressive and have pro-tumor function. Blocking the entry of TAMs into hypoxic regions inhibits their proangiogenic functions and can reverse or reduce the immunosuppressive microenvironment [101]. Specific deletion of HIF-1 $\alpha$ in myeloid cells in the MMTV-PyMT model of breast cancer leads to increased tumor cell apoptosis, elevated IFN- $\gamma$ production by TILs, and delayed tumor progression [105]. In this study, macrophage-mediated T cell suppression under hypoxia was demonstrated to be dependent on HIF-1 $\alpha$ and inducible nitric oxide synthetase (iNOS) [105]. In addition, co-culture of macrophages with hypoxic hepatoma cells induces the expression of indoleamine 2,3-dioxygenase (IDO) in macrophages, which also contributes to $\mathrm{T}$ cell suppression and Treg expansion [106]. Similarly, loss of HIF-2 $\alpha$ in macrophages results in reduced TAM infiltration by reducing the expression of M-CSFR and CXCR4 and improves tumor outcomes in hepatocellular and colon carcinoma models [107]. Besides the effects of hypoxia on TAM infiltration and T cell suppression, hypoxia also induces macrophages to produce increased matrix metalloproteinases (MMPs) including MMP2, 7, and 9, which remodel the ECM and contribute to tumor cell migration and invasion $[98,108]$. Transcriptome analysis of primary human macrophages cultured under hypoxic conditions identified upregulation of angiogenic factors such as VEGF, 
cyclooxygenase 2 (COX-2), angiopoietin, and fibroblast growth factor (FGF) [109] Consistently, HIF- $1 \alpha$-deficient macrophages cocultured with tumor spheroids demonstrate enhanced M2-type polarization with attenuated pro-angiogenic properties [110]. Studies have also demonstrated that a small molecule HIF-inhibitor, YC-1 attenuates peritoneal inflammation and proinflammatory M1-type macrophage polarization [111]. However, a recent study has pointed out that bone marrow-derived macrophages from animals with partial loss of the oxygen sensor PHD2 demonstrate more pronounced M2 polarization upon IL-4 stimulation and thus inhibition of PHD2 induces would healing, which indicates the complexity of hypoxia in regulating macrophage polarization [112].

In summary, TAMs tend to infiltrate into hypoxia/necrotic tumor regions, and the hypoxic microenvironment entraps these TAMs and induces an immunosuppressive phenotype, contributing to vessel formation, tumor progression and therapy resistance. Thus, full characterization of TAM plasticity within specific hypoxic and normoxic areas might provide guidance for therapy development and outcome prediction.

\subsection{Myeloid-Derived Suppressor Cells (MDSCs)}

Myeloid-derived suppressor cells (MDSCs) are a group of bone-marrow derived progenitor cells that are considered as precursors of macrophages, dendritic cells, granulocytes, and other mature myeloid cells. MDSCs are generally considered to have immunosuppressive functions in tumors [113]. MDSCs accumulate significantly in tumors and exploit multiple mechanisms to regulate innate and adaptive immune responses [114]. For example, MDSCs promote Treg differentiation and expansion by secreting immunosuppressive cytokines such as IL-10 and TGF- $\beta$ [114,115]. MDSCs can also produce arginase- 1 , which depletes arginine, an essential amino acid required for lymphocyte activity. MDSCs also produce reactive oxygen species, which can directly inhibit cytotoxic $\mathrm{T}$ cell proliferation and function $[113,116]$.

Hypoxia supports the immunosuppressive function of MDSCs and is a driver of MDSC recruitment [117]. Hypoxia sensing mainly via HIF- $1 \alpha$ has been shown to differentiate MDSCs into macrophages and dendritic cells (DCs), thus altering MDSCs function in the tumor site. Similarly, exposure of splenic MDSCs to hypoxia showed similar conversion of MDSCs [118]. In addition, hypoxia culture condition and hypoxic conditioning of liver by cobalt chloride treatment dramatically increase programmed death-ligand 1 (PD-L1) expression on splenic MDSCs isolated from multiple syngeneic tumor models. Mechanistic studies revealed that the upregulation of PD-L1 is regulated by HIF- $1 \alpha$ direct binding to the hypoxia response elements (HREs) in the PD-L1 proximal promoter. As a consequence, the suppressive capacity of MDSC on T cell proliferation is enhanced by hypoxia and blocking the increased PD-L1 expression abrogates MDSC-mediated T cell suppression [119]. HIF-1 $\alpha$ can also bind to a HRE in the miR-210 proximal promoter and elevate miR-210 expression, which contributes to enhanced MDSC-mediated T cell suppression [120]. In a recent study in colorectal cancer patients, HIF-1 $\alpha$ activity was shown to be associated with V-domain Ig suppressor of $\mathrm{T}$ cell activation (VISTA) expression, a negative checkpoint molecule in the B7 family [121]. Subsequent studies in mouse models illustrated that in profound hypoxic regions of tumors, HIF-1 $\alpha$ upregulates VISTA expression on tumor-infiltrating MDSCs by direct binding to the promoter, thus promoting the immune suppressive function of MDSCs [121]. Interestingly, hyperoxia (60\% oxygen) therapy in the $4 \mathrm{~T} 1$ triple negative breast cancer model decreases MDSCs expansion and PD-L1 expression in primary and metastatic sites [122]. In general, these studies suggest the enhanced suppressive capacity of MDSCs under hypoxia and demonstrate an additional mechanism by which hypoxia signaling in stromal cells contributes to immunosuppression.

\subsection{Dendritic Cells}

Dendritic cells (DCs) originate from hematopoietic progenitor cells and are a group of professional APCs responsible for T cells priming and initiation of antigen-specific antitumor immune responses [123]. In the absence of environmental stimuli, DCs exist in 
their immature form with low expression of co-stimulatory molecules and limited capacity for antigen presentation. However, after exposure to bacterial or viral products during infection and proinflammatory cytokines in the tumor microenvironment, DCs undergo maturation and are activated, which allows DCs to present antigens efficiently [123]. Activated DCs express higher levels of major histocompatibility complex (MHC) and costimulatory molecules as well as produce cytokines such as IL-12 and IFN $\alpha$ [124]. However, in the tumor microenvironment, DC maturation and function can be disrupted by production of VEGF, IL-10, IL-6, and decreased co-stimulatory molecule expression [125,126]. In addition, tumor cells are sufficient to convert a subset of immature DCs into TGF- $\beta$-secreting regulatory cells that promote the proliferation of Tregs [127].

There are controversial reports regarding the effects of hypoxia on DCs. Hypoxia has been shown to promote the differentiation and migration of DCs through HIF- $1 \alpha$ and PI3K/Akt signaling [128,129]. Hypoxia combined with LPS stimulation of DCs leads to upregulated co-stimulatory molecules, enhanced proinflammatory cytokines production and capacity of DCs to stimulate T cells proliferation, which are HIF- $1 \alpha$-dependent [130]. In particular, monocyte-derived DCs generated under hypoxic conditions upregulate triggering receptor expressed on myeloid cells (TREM-1), a hypoxia-induced gene that is responsible for upregulation of costimulatory molecules and secretion of proinflammatory cytokines [131-133]. Accordingly, DCs deficient in HIF-1 $\alpha$, when co-cultured with T cells, lead to decreased expression of CD278 and granzyme $B$ in T cells.

In contrast, studies have also demonstrated that in a 3D culture system, hypoxia suppresses maturation of monocyte-derived immature DCs, resulting in decreased motility and phagocytosis [134]. In addition, chronic exposure to hypoxia can induce a cell death program in DCs [135]. Hypoxia can also alter DC phenotype and skew a Th2 polarization of T cells with immunosuppressive cytokine production by upregulating CD44 expression on the surface of DCs [136]. A recent study has indicated that HIF- $1 \alpha$ expression in DCs promotes production of immune-inhibitory cytokines and conditional deletion of HIF- $1 \alpha$ in DCs enhances their capacity to stimulate T cell response [137]. Furthermore, inhibition of HIF- $1 \alpha$ was reported to improve the efficacy of a DC-based vaccine in $4 \mathrm{~T} 1$ breast cancer model. This was achieved by enhanced cytotoxic T cell proliferation, activity, and IFN- $\gamma$ production [138]. These contradictory effects of hypoxia on DCs indicate the importance of physiologically appropriate levels of HIF signaling as short-term and prolonged exposure to hypoxia might have different effects on migration and maturation of DCs [128,135].

The effects of HIF signaling in immune cell biology are summarized in Figure 2. 


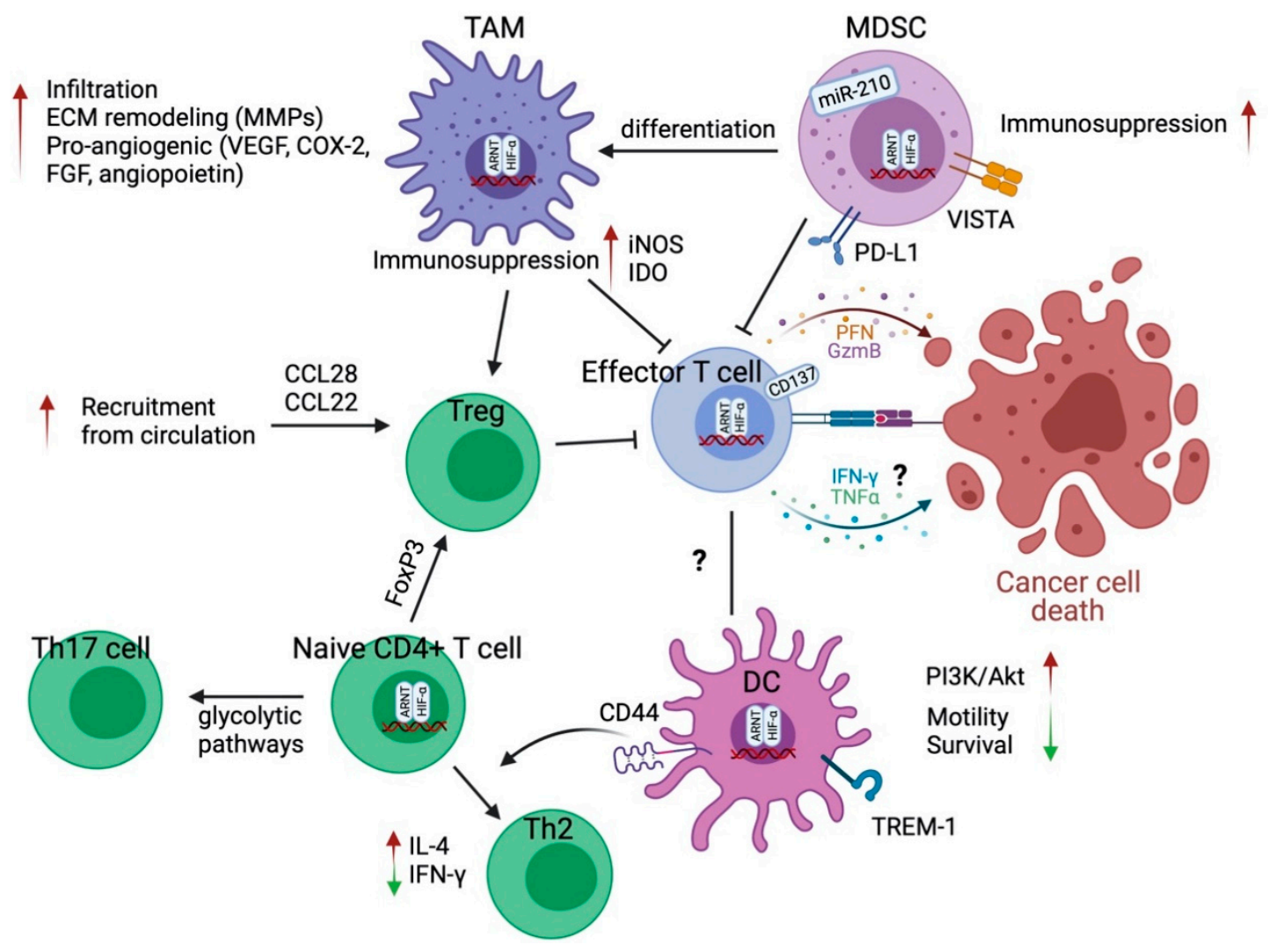

Figure 2. HIF signaling effects on immune cells in the tumor microenvironment. HIF signaling, mainly HIF- $1 \alpha$ generally promotes an immunosuppressive microenvironment. In TAMs and MDSCs, HIF-1 $\alpha$ contributes to their infiltration and enhanced suppressive capacity on effector T cells. HIF- $1 \alpha$ can also stimulate a proangiogenic phenotype of TAMs and TAM-mediated ECM remodeling. The hypoxic microenvironment stimulates the secretion of cytokines and chemokines from tumor cells or TAMs to recruit Tregs, further limiting effector T cell function. There is conflicting evidence of HIF signaling in determining $\mathrm{T}$ cell fate. HIF- $1 \alpha$ has been demonstrated to induce or inhibit differentiation of naïve CD4 ${ }^{+} \mathrm{T}$ cells into Th17 T cells or Tregs. HIF-1 $\alpha$ signaling also exhibits controversial effects on effector $\mathrm{T}$ cell function and the migration and maturation of DCs. The effect of hypoxia on DC and T cell interaction is an area ripe for further investigation. Green arrow pointing down, decreased; red arrow pointing up, increased.

\section{Targeting Hypoxia and HIFs in Cancer}

There are multiple strategies for therapeutically targeting tumor hypoxia including hypoxia activated prodrugs (HAPs), inhibitors of HIF-1, HIF-2, and inhibitors of the associated signaling pathways.

\subsection{Hypoxia Activated Prodrugs (HAPs)}

HAPs are designed to be specifically activated in hypoxic environments and undergo electron reduction to generate an active cytotoxic effector leading to cell death. HAPs are classified by chemical structure and separated into five classes: nitroimidazoles/nitroaromatics, quinones, aromatic n-oxides, aliphatic n-oxides and transition metals [139]. Although there are numerous HAPs that exhibited promising pre-clinical outcomes, the efficacy in clinical trials has been limited, thus far.

Tirapazamine was the first HAP that was developed and tested in clinical trials [140]. It is an aromatic n-oxide compound that is activated to a transient oxidizing radical under hypoxia inducing DNA damage via topoisomerase II [139]. It has been investigated in numerous clinical trials in combination with radiotherapy or cytotoxic chemotherapy for solid tumors including cervical, head and neck, NSCLC, advanced pediatric cancers (NCT00262821, NCT00094081, NCT00006484, NCT00003288) [141]. Overall, the results of 
phase III studies have been disappointing, and no consistent therapeutic benefit has been identified [142].

TH-302 (evofosfamide), a nitroimidazole, crosslinks DNA in hypoxic tissues, inhibiting cell proliferation and inducing apoptosis [141]. There are extensive preclinical data showing the efficacy of TH-302 as a monotherapy and in combination with standard chemoor radiotherapy in pancreatic adenocarcinoma, sarcoma, neuroblastoma, and renal cell carcinoma mouse models [143-148]. Unfortunately, three phase III clinical trials for pancreatic adenocarcinoma (NCT01746979), soft tissue sarcoma (NCT01440088), and esophageal carcinoma (NCT02598687) were discontinued as no effects were seen [149,150].

There are several additional HAPs (TH-4000, apaziquone, banoxantrone, PR-104) that have been developed and advanced to clinical trials but unfortunately have had similar discouraging results. There are many reviews detailing the preclinical and clinical results of HAPs [141,151].

\subsection{Inhibitors of HIF}

Given that HIF-1 and HIF-2 are highly expressed in a majority of malignancies, inhibitors targeting HIF and HIF signaling are being evaluated widely preclinically and clinically [152].

NLG207 (formerly named CRLX101) is a nanoparticle drug conjugate containing camptothecin, a potent topoisomerase I and HIF- $1 \alpha$ inhibitor that accumulates in solid tumors and is slowly released over an extended period of time [153]. NLG207 has demonstrated effective targeting of HIF- $1 \alpha$ and angiogenesis in models of breast, prostate cancer, and glioblastoma, as monotherapy or in combination with standard therapies, resulting in inhibition of tumor growth and improved animal survival [154-157]. In preclinical prostate cancer models, it has recently been demonstrated to improve effects of enzalutamide on previously resistant tumors [158]. It is currently in phase II clinical trials in combination with bevacizumab in ovarian and peritoneal cancer (NCT01652079) [159] and enzalutamide in prostate cancer (NCT03531827) [158].

PT2385 is a direct small molecule inhibitor of HIF-2 $\alpha$. The compound prevents dimerization with HIF- $\beta$, inhibiting downstream signaling effects [160]. In preclinical renal cell carcinoma mouse models and patient-derived xenografts, treatment with PT2385 and its analog, PT2399, displays significant suppression of tumor growth, invasion, and angiogenesis $[160,161]$. It is currently being evaluated in clinical trials for glioblastoma and clear cell renal cell carcinoma (NCT03216499, NCT03108066) [162,163].

Indirect inhibition of HIF can also be achieved through the blockade of associated signaling pathways, such as PI3K/AKT/mTOR and MAPK/ERK pathways. These signaling cascades further activate or enhance HIF-1 $\alpha$ synthesis [152]. For example, sirolimus, an mTOR inhibitor has shown encouraging results in preclinical and clinical studies in prostate cancer $[164,165]$. Furthermore, metformin indirectly inhibits mTORC1 through activation of the AMPK pathway and has also demonstrated promising results [166]. Furthermore, in preclinical models, metformin has been linked to increased $\mathrm{T}$ cell activation, working synergistically with checkpoint blockade [167]. It is currently being studied in several ongoing trials for breast, endometrial, colorectal, prostate, and oral cancers (NCT01101438, NCT01697566, NCT02614339, NCT01864096, NCT03685409, NCT02581137) [149]. In addition, Minnelide by targeting p300 and heat shock protein 70 inhibits the transcriptional activity of HIF- $1 \alpha$. Minnelide has shown promising effects in reduction of tumor burden and metastasis in preclinical models and is currently under investigation in a phase II clinical trial for refractory pancreatic cancer (NCT03117920) [168].

\subsection{Combination with Immune Checkpoint Inhibitors}

Although hypoxia targeted therapies have not elicited significant response as a monotherapy and efficacy in combination with standard chemo- and radiotherapy is still under investigation, there are growing evidence to support the combination of hypoxiatargeted strategies with immunotherapy. As previously described, hypoxia induces an 
immunosuppressive microenvironment by creating dense stroma, inducing barriers to T cell infiltration, increasing MDSCs, and other immunosuppressive myeloid cells [169]. Hypoxic tumors demonstrate few, if any, T cells, and therefore cannot exhibit a robust response to immune checkpoint blockade [170]. Therefore, inhibiting hypoxia might alter the immunosuppressive tumor microenvironment to improve cytotoxic $\mathrm{T}$ cell infiltration and function [170]. In transgenic mice bearing prostate adenocarcinoma, combination of TH-302 (evofosfamide) with anti-PD-1/anti-CTLA-4 achieved an 80\% cure rate and resulted in an adaptive antitumor response with immune memory [170]. Meanwhile, this combination also increased T cell proliferation, cytotoxic potential and effector cytokine production while mice without evofosfamide were completely resistant to immune checkpoint blockade [170]. Based on these promising results, a phase I trial of TH-302 and ipilimumab (NCT03098160) for advanced solid malignancies is underway [170]. In addition, the effects of hypoxia on the efficacy of immune checkpoint inhibitors, nivolumab and ipilimumab, are being explored in a clinical trial (NCT03003637) [171]. This trial will exploit the use of F-HX4, a hypoxia-specific PET scan radiotracer, to guide biopsies of hypoxic and normoxic tumor tissue. T cell infiltration and effector function pre- and post-immune checkpoint blockade will be compared amongst tumor tissues with varied oxygenation status [171].

\subsection{Combination with Anti-Angiogenesis Therapy}

In addition to combination with immune checkpoint blockade, there is increasing interest in the combination of anti-angiogenic therapies with hypoxia targeted treatments. One mechanism of resistance to anti-angiogenic therapy is through the induction of hypoxia and upregulation of HIF- $1 \alpha$ and HIF- $2 \alpha$ [172]. Studies have suggested that by adding low dose anti-angiogenic agents, the tumor vasculature could be normalized which should enhance drug delivery [173]. However, it is critical to maintain anti-angiogenic agents at a fine balance as high doses may lead to avascularization of the tumor bed, worsening tumor hypoxia. The combination of TH-302 with anti-angiogenic agents (pazopanib, sunitinib, and DC101) have been evaluated in melanoma, sarcoma, and neuroblastoma mouse models resulting in consistent improved outcomes and decreased tumor growth [174-176], leading to the development of phase I/II clinical trials. Furthermore, the combination of TH-302 with bevacizumab is being studied in glioblastoma and high-grade glioma. In a phase II clinical trial, this combination therapy lengthened progression free survival to 4 months in $31 \%$ of patients with glioblastoma (NCT02342379) [177]. Another upcoming development is a nanoparticle drug to combine TH-302 (evofosfamide) with an anti-angiogenic/vascular disrupting agent (combretastatin). Combretastatin is bound to the external layer of the nanoparticle and TH-302 is enveloped inside. By releasing combretastatin first from the surface, the tumor vasculature can be normalized, facilitating nanoparticle delivery to the tumor, potentially releasing TH-302 with greater efficacy [178].

Ongoing clinical trials targeting tumor hypoxia have been summarized in Table 1. 
Table 1. Ongoing clinical trials targeting and evaluating hypoxia in the tumor microenvironment.

\begin{tabular}{|c|c|c|c|c|c|}
\hline Clinical Trial & Trial Phase & Drug & Mechanism & Disease & References \\
\hline \multicolumn{6}{|c|}{ Hypoxia activated prodrug } \\
\hline NCT03224182 & III & Apaziquone & Indolequinone & Non-muscle invasive bladder cancer & Clinicaltrials.gov \\
\hline $\begin{array}{l}\text { NCT01880359 } \\
\text { NCT02661152 }\end{array}$ & III & Nimorazole + chemoradiotherapy & $\begin{array}{l}\text { 5-nitroimidazoles, } \\
\text { radiosensitizer }\end{array}$ & $\begin{array}{l}\text { Locally advanced head and neck squamous } \\
\text { cell cancer }\end{array}$ & Clinicaltrials.gov \\
\hline NCT03531827 & II & NLG207 + enzalutamide & $\begin{array}{l}\text { HIF- } 1 \alpha / \text { topoisomerase I } \\
\text { inhibitor + antiandrogen }\end{array}$ & Metastatic prostate cancer & [158] \\
\hline $\begin{array}{l}\text { NCT02769962 } \\
\text { NCT04669002 }\end{array}$ & $\mathrm{I} / \mathrm{II}$ & EP0057 + olaparib & $\begin{array}{l}\text { HIF-1 } \alpha / \text { topoisomerase I } \\
\text { inhibitor + PARP inhibitor }\end{array}$ & $\begin{array}{c}\text { Relapsed/refractory small cell lung cancer } \\
\text { Ovarian cancer }\end{array}$ & Clinicaltrials.gov \\
\hline $\begin{array}{l}\text { NCT03108066 } \\
\text { NCT03216499 }\end{array}$ & II & PT2385 & HIF- $2 \alpha$ inhibitor & $\begin{array}{c}\text { Von Hippel-Lindau associated clear cell } \\
\text { renal carcinoma } \\
\text { Glioblastoma }\end{array}$ & Clinicaltrials.gov \\
\hline NCT04195750 & III & Belzutifan (MK-6482) & HIF-2 $\alpha$ inhibitor & Advanced renal cell carcinoma & Clinicaltrials.gov \\
\hline \multicolumn{6}{|c|}{ Targeting Associated pathways } \\
\hline $\begin{array}{l}\text { NCT01101438 } \\
\text { NCT01864096 } \\
\text { NCT01697566 } \\
\text { NCT03685409 }\end{array}$ & III & Metformin & $\begin{array}{l}\text { Decreases HIF-1 } \alpha \\
\text { accumulation }\end{array}$ & $\begin{array}{c}\text { Early-stage breast cancer } \\
\text { Low risk prostate cancer } \\
\text { Chemoprevention study in endometrial and } \\
\text { oral cancer }\end{array}$ & [149] \\
\hline NCT02614339 & III & $\begin{array}{l}\text { Metformin + traditional } \\
\text { chemotherapy }\end{array}$ & $\begin{array}{l}\text { Decreases HIF-1 } \alpha \\
\text { accumulation }\end{array}$ & Recurrent colorectal cancer & [149] \\
\hline NCT04275713 & II & Metformin + cisplatin & $\begin{array}{l}\text { Decreases HIF-1 } \alpha \\
\text { accumulation }\end{array}$ & Locally advanced cervical cancer & $\begin{array}{c}{[179]} \\
\text { Clinicaltrials.gov }\end{array}$ \\
\hline NCT03117920 & II & Minnelide & HSP70, p300 inhibitors & Refractory pancreatic cancer & [149] \\
\hline NCT03450018 & $\mathrm{I} / \mathrm{II}$ & SLC0111+ gemcitabine & CAIX & Metastatic pancreatic cancer & [180] \\
\hline
\end{tabular}


Table 1. Cont.

\begin{tabular}{|c|c|c|c|c|c|}
\hline Clinical Trial & Trial Phase & Drug & Mechanism & Disease & References \\
\hline $\begin{array}{l}\text { NCT04648033 } \\
\text { NCT02628080 }\end{array}$ & I & Atovaquone + chemoradiotherapy & $\begin{array}{l}\text { Antimalarial drug; Hypoxia } \\
\text { modifier via inhibition of } \\
\text { mitochondrial complex III }\end{array}$ & Locally advanced non-small cell lung cancer & $\begin{array}{c}{[180]} \\
\text { Clinicaltrials.gov }\end{array}$ \\
\hline NCT03098160 & I & TH-302 + ipilimumab & $\mathrm{HAP}+$ anti-CTLA4 Ab & Advanced solid malignancies & [170] \\
\hline NCT01652079 & II & NLG207 + bevacizumab & $\begin{array}{l}\text { HIF- } 1 \alpha / \text { topoisomerase I } \\
\text { inhibitor + anti-VEGF Ab }\end{array}$ & Ovarian/peritoneal cancer & [158] \\
\hline NCT03634540 & II & Belzutifan (PT2977) + cabozantinib & HIF-2 $\alpha+$ VEGFR2 inhibitors & Advanced clear cell renal carcinoma & Clinicaltrials.gov \\
\hline NCT04895748 & $\mathrm{I} / \mathrm{Ib}$ & $\begin{array}{l}\text { DFF332 + everolimus }+ \\
\text { spartalizumab }\end{array}$ & $\begin{array}{l}\text { HIF- } 2 \alpha \text { inhibitor + mTOR } \\
\text { inhibitor + anti-PD- } 1 \mathrm{Ab}\end{array}$ & $\begin{array}{l}\text { Relapsed renal cell carcinoma, advanced } \\
\text { malignancies with HIF stabilizing mutations }\end{array}$ & Clinicaltrials.gov \\
\hline \multirow[t]{2}{*}{ NCT04114136 } & II & $\begin{array}{l}\text { Metformin or rosiglitazone }+ \\
\text { nivolumab or pembrolizumab }\end{array}$ & $\begin{array}{l}\text { Decreases HIF-1 } \alpha \\
\text { accumulation }\end{array}$ & Advanced solid tumor malignancies & Clinicaltrials.gov \\
\hline & & Assessment of hypoxia & & & \\
\hline NCT03003637 & $\mathrm{IB} / \mathrm{II}$ & 18F-FDG PET-CT & $\begin{array}{l}\text { Pre and post nivolumab +/- } \\
\text { ipilimumab }\end{array}$ & $\begin{array}{l}\text { Advanced/recurrent head and neck } \\
\text { carcinoma }\end{array}$ & [171] \\
\hline NCT03373994 & & 18F-FDG PET-CT & $\begin{array}{c}\text { Evaluate tumor perfusion } \\
\text { and hypoxia }\end{array}$ & Solid tumors & Clinicaltrials.gov \\
\hline NCT03646747 & & Oxygen enhanced MRI measurement & Pre and post radiotherapy & Head and neck cancer & Clinicaltrials.gov \\
\hline NCT04309552 & & FMISO, FLT PET & $\begin{array}{l}\text { Compare FMISO, FLT PET vs. } \\
\text { molecular biomarkers of } \\
\text { hypoxia and cell proliferation }\end{array}$ & High grade glioma & Clinicaltrials.gov \\
\hline NCT02095249 & & $\begin{array}{l}\text { Pimonidazole followed by } \\
\text { prostatectomy }\end{array}$ & $\begin{array}{l}\text { Measure tumor hypoxia via } \\
\text { immunohistochemical } \\
\text { staining }\end{array}$ & Prostate cancer & Clinicaltrials.gov \\
\hline NCT04001023 & & $\begin{array}{l}\text { 18F-EF5 PET-CT and targeted tumor } \\
\text { sampling }\end{array}$ & $\begin{array}{c}\text { Identify molecular } \\
\text { differences between hypoxic } \\
\text { and non-hypoxic tumors }\end{array}$ & Advanced ovarian cancer & Clinicaltrials.gov \\
\hline
\end{tabular}


Table 1. Cont.

\begin{tabular}{|c|c|c|c|c|c|}
\hline Clinical Trial & Trial Phase & Drug & Mechanism & Disease & References \\
\hline NCT00568490 & & $\begin{array}{l}\text { Osteopontin, lysyl oxidase, } \\
\text { macrophage inhibiting factor and } \\
\text { proteomic technology }\end{array}$ & $\begin{array}{l}\text { Identify hypoxic biomarkers } \\
\text { in blood and tumors }\end{array}$ & $\begin{array}{l}\text { Head and neck cancer } \\
\text { Lung cancer }\end{array}$ & Clinicaltrials.gov \\
\hline NCT03054792 & & 18F-FAZA/BOLD PET-MRI & $\begin{array}{l}\text { Measure hypoxia between } \\
\text { start and completion of } \\
\text { treatment }\end{array}$ & Pediatric sarcomas & Clinicaltrials.gov \\
\hline \multicolumn{6}{|c|}{ Hypoxia assessment + radiotherapy } \\
\hline NCT02352792 & II & FMISO PET + radiation & $\begin{array}{l}\text { Hypoxic tumors receive } 10 \% \\
\text { higher dose of radiation }\end{array}$ & Head and neck squamous cell carcinoma & Clinicaltrials.gov \\
\hline
\end{tabular}

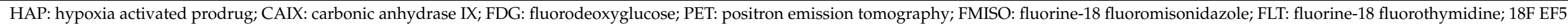
fluorine-18 EF5; 18F-FAZA/BOLD: F18-fluoroazomycin arabinoside/blood oxygen level dependent; MRI: magnetic resonance imaging. 


\section{Conclusions}

Hypoxia is a common feature of solid tumors and has profound effects on cancer cells and stromal components. Due to tumor heterogeneity, different cell types and tumor components respond differently to hypoxia, highlighting the complexity of this field. Stabilization of HIF under hypoxic conditions upregulates proangiogenic factors and modulates vessel maturation, further contributing to tumor angiogenesis and progression. Hypoxia also promotes ECM remodeling and regulates CAF activation that support tumor growth and metastasis. In addition, hypoxia drives recruitment of immune suppressor cells and modulates phenotype or paracrine factors secretion of immune cells, thereby promoting an immunosuppressive microenvironment which compromises the effects of immunotherapy. However, multiple issues remain to be clarified regarding the specific function of the main sensors of hypoxia. For example, HIF- $1 \alpha$ exhibits effects in CAFs, $\mathrm{T}$ cells, and DCs in a context-dependent manner, reinforcing the difficulty of targeting hypoxia globally and the importance of developing combination therapies or strategies to overcome the challenges associated with therapeutic targeting of an environmental condition. Combination with immune checkpoint inhibitors and anti-angiogenic therapy is an active investigation and that has potential efficacy in early clinical trials. Moreover, pharmacologic inhibition of PHD enzyme function upregulates HIF signaling and the expression of HIF target genes, which could be applied to treat patients with anemia due to chronic kidney disease and other fibrotic diseases [181]. However, short-term treatment with PHD inhibitors did not show favorable effects on tumor initiation and progression in clinical trials [182]. Interestingly, in a spontaneous breast cancer model, chronic treatment with PHD inhibitors induced erythropoiesis but did not show effects on tumor initiation, progression and metastasis [183]. Further, a pan-PHD inhibitor (DMOG) was reported to limit metastasis in $4 \mathrm{~T} 1$ breast tumor model [61]. These studies complicated the field of targeting hypoxia. Timing, length of treatment and appropriate disease models are worth considering for optimizing hypoxia-targeted therapies or PHD inhibitors.

Although hypoxia-targeted therapies have achieved efficacy in preclinical models, rare success has been reported in clinical trials. A challenge to this class of targeted therapy is thought to be secondary to narrow therapeutic windows. One strategy being explored to improve treatment response is the development of nanoparticles to allow time-controlled release and drive synergistic effects with other therapies. Another challenge contributing to the failure of prior clinical studies is the fact that the extent of tumor hypoxia has not been evaluated pre or post treatment [171]. Furthermore, previous clinical trials have not stratified patients based on hypoxia status and therefore inadvertently included malignancies that do not exhibit targetable hypoxic conditions. A critical step in improving the efficacy of hypoxia targeted therapies involves optimizing the assessment of hypoxia of individual tumors. There are direct and indirect ways to measure hypoxia (i.e., the placement of electrodes directly in the tumor bed, immunohistochemical staining). However, these modalities have numerous limitations [184]. The most feasible hypoxia assessments are oxygen-enhanced MRI or PET imaging with hypoxia-induced tracers [184]. There are current clinical trials evaluating the sensitivity and specificity of hypoxia targeted imaging (summarized in Table 1). With the challenge of significant intra-tumor heterogeneity, there is a clear unmet need for effective biomarkers to characterize tumor hypoxia. Improved understanding of intratumor heterogeneity of oxygenation and vascularization status would facilitate anti-hypoxia therapy that is tailored based on individual tumor characteristics.

Author Contributions: Conceptualization, Y.Z., M.C. and R.A.B.; writing—original draft preparation, Y.Z., M.C..; writing-review and editing, R.A.B.; All authors have read and agreed to the published version of the manuscript. All figures were created with BioRender.com.

Funding: This work was supported by NIH U54 CA210181 (Project 2), R01 CA243577 and the Effie Marie Cain Fellowship to RAB.

Institutional Review Board Statement: Not applicable. 
Informed Consent Statement: Not applicable.

Data Availability Statement: Not applicable.

Conflicts of Interest: The authors declare no conflict of interest.

\section{References}

1. Vaupel, P.; Mayer, A. Hypoxia in cancer: Significance and impact on clinical outcome. Cancer Metastasis Rev. 2007, 26, 225-239. [CrossRef]

2. LaGory, E.L.; Giaccia, A.J. The ever-expanding role of HIF in tumour and stromal biology. Nat. Cell Biol. 2016, 18, 356-365. [CrossRef]

3. Laitala, A.; Erler, J.T. Hypoxic signalling in tumour stroma. Front. Oncol. 2018, 8, 189. [CrossRef]

4. Majmundar, A.J.; Wong, W.J.; Simon, M.C. Molecular Cell Hypoxia-Inducible Factors and the Response to Hypoxic Stress. Mol. Cell 2010, 40, 294-309. [CrossRef]

5. Bertout, J.A.; Patel, S.A.; Simon, M.C. The impact of $\mathrm{O}_{2}$ availability on human cancer. Nat. Rev. Cancer. 2008, 8, 967-975. [CrossRef] [PubMed]

6. Yu, F.; White, S.B.; Zhao, Q.; Lee, F.S. HIF-1 $\alpha$ binding to VHL is regulated by stimulus-sensitive proline hydroxylation. Proc. Natl. Acad. Sci. USA 2001, 98, 9630-9635. [CrossRef]

7. Semenza, G.L. Hydroxylation of HIF-1: Oxygen sensing at the molecular level. Physiology 2004, 19, 176-182. [CrossRef] [PubMed]

8. Pouysségur, J.; Dayan, F.; Mazure, N.M. Hypoxia signalling in cancer and approaches to enforce tumour regression. Nature 2006, 441, 437-443. [CrossRef] [PubMed]

9. Pàez-Ribes, M.; Allen, E.; Hudock, J.; Takeda, T.; Okuyama, H.; Viñals, F.; Inoue, M.; Bergers, G.; Hanahan, D.; Casanovas, O. Antiangiogenic Therapy Elicits Malignant Progression of Tumors to Increased Local Invasion and Distant Metastasis. Cancer Cell. 2009, 15, 220-231. [CrossRef]

10. Welti, J.; Loges, S.; Dimmeler, S.; Carmeliet, P. Recent molecular discoveries in angiogenesis and antiangiogenic therapies in cancer. J. Clin. Investig. 2013, 123, 3190-3200. [CrossRef]

11. Huang, Y.; Yuan, J.; Righi, E.; Kamoun, W.S.; Ancukiewicz, M.; Nezivar, J.; Santosuosso, M.; Martin, J.D.; Martin, M.R.; Vianello, F.; et al. Vascular normalizing doses of antiangiogenic treatment reprogram the immunosuppressive tumor microenvironment and enhance immunotherapy. Proc. Natl. Acad. Sci. USA 2012, 109, 17561-17566. [CrossRef]

12. Aguilera, K.Y.; Rivera, L.B.; Hur, H.; Carbon, J.G.; Toombs, J.E.; Goldstein, C.D.; Dellinger, M.T.; Castrillon, D.H.; Brekken, R.A. Collagen signaling enhances tumor progression after anti-VEGF therapy in a murine model of pancreatic ductal adenocarcinoma. Cancer Res. 2014, 74, 1032-1044. [CrossRef] [PubMed]

13. Cenik, B.K.; Ostapoff, K.T.; Gerber, D.E.; Brekken, R.A. BIBF 1120 (nintedanib), a triple angiokinase inhibitor, induces hypoxia but not EMT and blocks progression of preclinical models of lung and pancreatic cancer. Mol. Cancer Ther. 2013, 12, 992-1001. [CrossRef] [PubMed]

14. Chen, Y.; Huang, Y.; Reiberger, T.; Duyverman, A.M.; Huang, P.; Samuel, R.; Hiddingh, L.; Roberge, S.; Koppel, C.; Lauwers, G.Y.; et al. Differential effects of sorafenib on liver versus tumor fibrosis mediated by stromal-derived factor 1 alpha/C-X-C receptor type 4 axis and myeloid differentiation antigen-positive myeloid cell infiltration in mice. Hepatology 2014, 59, $1435-1447$. [CrossRef] [PubMed]

15. Rahbari, N.N.; Kedrin, D.; Incio, J.; Liu, H.; Ho, W.W.; Nia, H.T.; Edrich, C.M.; Jung, K.; Daubriac, J.; Chen, I.; et al. Anti-VEGF therapy induces ECM remodeling and mechanical barriers to therapy in colorectal cancer liver metastases. Sci. Transl. Med. 2016, 8, 360ra135. [CrossRef] [PubMed]

16. Keith, B.; Johnson, R.S.; Simon, M.C. HIF1 $\alpha$ and HIF2 $\alpha$ : Sibling rivalry in hypoxic tumour growth and progression. Nat. Rev. Cancer 2012, 12, 9-22. [CrossRef]

17. Gunda, V.; Kumar, S.; Dasgupta, A.; Singh, P.K. Hypoxia-induced metabolomic alterations in pancreatic cancer cells. In Methods in Molecular Biology; Humana Press Inc.: Totowa, NJ, USA, 2018; Volume 1742, pp. 95-105. [CrossRef]

18. Muz, B.; de la Puente, P.; Azab, F.; Azab, A.K. The role of hypoxia in cancer progression, angiogenesis, metastasis, and resistance to therapy. Hypoxia 2015, 3, 83. [CrossRef]

19. Bristow, R.G.; Hill, R.P. Hypoxia and metabolism: Hypoxia, DNA repair and genetic instability. Nat. Rev. Cancer 2008, 8, 180-192. [CrossRef]

20. Wilson, W.R.; Hay, M.P. Targeting hypoxia in cancer therapy. Nat. Rev. Cancer 2011, 11, 393-410. [CrossRef]

21. Jain, R.K. Normalization of tumor vasculature: An emerging concept in antiangiogenic therapy. Science 2005, 307, 58-62. [CrossRef]

22. Carmeliet, P.; Jain, R.K. Principles and mechanisms of vessel normalization for cancer and other angiogenic diseases. Nat. Rev. Drug Discov. 2011, 10, 417-427. [CrossRef] [PubMed]

23. Ochocka, R.; Dell'Italia, L.; Bartoszewska, S.; Króliczewski, J.; Dabrowski, M.; Collawn, J.F. Primary endothelial-specific regulation of hypoxiainducible factor (HIF)-1 and HIF-2 and their target gene expression profiles during hypoxia. FASEB J. 2019, 33, 7929. [CrossRef]

24. Serocki, M.; Bartoszewska, S.; Janaszak-Jasiecka, A.; Ochocka, R.J.; Collawn, J.F.; Bartoszewski, R. miRNAs regulate the HIF switch during hypoxia: A novel therapeutic target. Angiogenesis 2018, 21, 183-202. [CrossRef] [PubMed] 
25. Tang, N.; Wang, L.; Esko, J.; Giordano, F.J.; Huang, Y.; Gerber, H.P.; Ferrara, N.; Johnson, R.S. Loss of HIF-1 $\alpha$ in endothelial cells disrupts a hypoxia-driven VEGF autocrine loop necessary for tumorigenesis. Cancer Cell. 2004, 6, 485-495. [CrossRef] [PubMed]

26. Branco-Price, C.; Zhang, N.; Schnelle, M.; Evans, C.; Katschinski, D.M.; Liao, D.; Ellies, L.; Johnson, R.S. Endothelial cell HIF-1 $\alpha$ and HIF-2 $\alpha$ differentially regulate metastatic success. Cancer Cell. 2012, 21, 52-65. [CrossRef] [PubMed]

27. Skuli, N.; Liu, L.; Runge, A.; Wang, T.; Yuan, L.; Patel, S.; Iruela-Arispe, L.; Simon, M.C.; Keith, B. Endothelial deletion of hypoxia-inducible factor- $2 \alpha$ (HIF-2 $\alpha$ ) alters vascular function and tumor angiogenesis. Blood 2009, 114, 469-477. [CrossRef]

28. Skuli, N.; Majmundar, A.J.; Krock, B.L.; Mesquita, R.C.; Mathew, L.K.; Quinn, Z.L.; Runge, A.; Liu, L.; Kim, M.N.; Liang, J.; et al. Endothelial HIF- $2 \alpha$ regulates murine pathological angiogenesis and revascularization processes. J. Clin. Investig. 2012, 122, 1427-1443. [CrossRef]

29. Krock, B.L.; Skuli, N.; Simon, M.C. Hypoxia-Induced Angiogenesis: Good and Evil. Genes Cancer 2011, 2, 1117-1133. [CrossRef]

30. Mazzone, M.; Dettori, D.; de Oliveira, R.L.; Loges, S.; Schmidt, T.; Jonckx, B.; Tian, Y.M.; Lanahan, A.A.; Pollard, P.; de Almodovar, C.R.; et al. Heterozygous Deficiency of PHD2 Restores Tumor Oxygenation and Inhibits Metastasis via Endothelial Normalization. Cell 2009, 136, 839-851. [CrossRef]

31. Kuchnio, A.; Moens, S.; Bruning, U.; Kuchnio, K.; Cruys, B.; Thienpont, B.; Broux, M.; Ungureanu, A.A.; de Oliveira, R.L.; Bruyère, F.; et al. The cancer cell oxygen sensor PHD2 promotes metastasis via activation of cancer-associated fibroblasts. Cell Rep. 2015, 12, 992-1005. [CrossRef]

32. Pickup, M.W.; Mouw, J.K.; Weaver, V.M. The extracellular matrix modulates the hallmarks of cancer. EMBO Rep. 2014, 15, 1243-1253. [CrossRef]

33. Huang, H.; Wright, S.; Zhang, J.; Brekken, R.A. Getting a grip on adhesion: Cadherin switching and collagen signaling. Biochim. Biophys. Acta Mol. Cell Res. 2019, 1866, 118472. [CrossRef]

34. Frantz, C.; Stewart, K.M.; Weaver, V.M. The extracellular matrix at a glance. J. Cell Sci. 2010, 123, 4195-4200. [CrossRef]

35. Levental, K.R.; Yu, H.; Kass, L.; Lakins, J.N.; Egeblad, M.; Erler, J.T.; Fong, S.F.; Csiszar, K.; Giaccia, A.; Weninger, W.; et al. Matrix Crosslinking Forces Tumor Progression by Enhancing Integrin Signaling. Cell 2009, 139, 891-906. [CrossRef] [PubMed]

36. Provenzano, P.P.; Cuevas, C.; Chang, A.E.; Goel, V.K.; Von Hoff, D.D.; Hingorani, S.R. Enzymatic Targeting of the Stroma Ablates Physical Barriers to Treatment of Pancreatic Ductal Adenocarcinoma. Cancer Cell 2012, 21, 418-429. [CrossRef] [PubMed]

37. Anderson, K.G.; Stromnes, I.M.; Greenberg, P.D. Obstacles Posed by the Tumor Microenvironment to T cell Activity: A Case for Synergistic Therapies. Cancer Cell 2017, 31, 311-325. [CrossRef] [PubMed]

38. Kalluri, R. The biology and function of fibroblasts in cancer. Nat. Rev. Cancer 2016, 16, 582-598. [CrossRef]

39. Räsänen, K.; Vaheri, A. Activation of fibroblasts in cancer stroma. Exp. Cell Res. 2010, 316, 2713-2722. [CrossRef]

40. Özdemir, B.C.; Pentcheva-Hoang, T.; Carstens, J.L.; Zheng, X.; Wu, C.C.; Simpson, T.R.; Laklai, H.; Sugimoto, H.; Kahlert, C.; Novitskiy, S.V.; et al. Depletion of carcinoma-associated fibroblasts and fibrosis induces immunosuppression and accelerates pancreas cancer with reduced survival. Cancer Cell 2014, 25, 719-734. [CrossRef] [PubMed]

41. Huang, H.; Brekken, R.A. The next wave of stroma-targeting therapy in pancreatic cancer. Cancer Res. 2019, 79, 328-330. [CrossRef] [PubMed]

42. Öhlund, D.; Handly-Santana, A.; Biffi, G.; Elyada, E.; Almeida, A.S.; Ponz-Sarvise, M.; Corbo, V.; Oni, T.E.; Hearn, S.A.; Lee, E.J.; et al. Distinct populations of inflammatory fibroblasts and myofibroblasts in pancreatic cancer. J. Exp. Med. 2017, 214, 579-596. [CrossRef]

43. LeBleu, V.S.; Kalluri, R. A peek into cancer-associated fibroblasts: Origins, functions and translational impact. DMM Dis. Model. Mech. 2018, 11. [CrossRef]

44. Costa, A.; Kieffer, Y.; Scholer-Dahirel, A.; Pelon, F.; Bourachot, B.; Cardon, M.; Sirven, P.; Magagna, I.; Fuhrmann, L.; Bernard, C.; et al. Fibroblast Heterogeneity and Immunosuppressive Environment in Human Breast Cancer. Cancer Cell 2018, 33, 463-479. [CrossRef]

45. Huang, H.; Wang, Z.; Zhang, Y.; Brekken, R. Mesothelial Cell-Derived Antigen-Presenting Cancer-Associated Fibroblasts Induce Expansion of Regulatory T Cells in Pancreatic Cancer. bioRxiv 2021. [CrossRef]

46. Myllyharju, J.; Schipani, E. Extracellular matrix genes as hypoxia-inducible targets. Cell Tissue Res. 2010, 339, 19-29. [CrossRef]

47. Goggins, E.; Kakkad, S.; Mironchik, Y.; Jacob, D.; Wildes, F.; Krishnamachary, B.; Bhujwalla, Z.M. Hypoxia Inducible Factors Modify Collagen I Fibers in MDA-MB-231 Triple Negative Breast Cancer Xenografts. Neoplasia 2018, 20, 131-139. [CrossRef] [PubMed]

48. Semenza, G.L. The hypoxic tumor microenvironment: A driving force for breast cancer progression. Biochim. Biophys. Acta Mol. Cell Res. 2016, 1863, 382-391. [CrossRef] [PubMed]

49. Gilkes, D.M.; Bajpai, S.; Wong, C.C.; Chaturvedi, P.; Hubbi, M.E.; Wirtz, D.; Semenza, G.L. Cell Death and Survival Procollagen Lysyl Hydroxylase 2 Is Essential for Hypoxia-Induced Breast Cancer Metastasis. Mol. Cancer Res. 2013, 11, 456-466. [CrossRef] [PubMed]

50. Myllyharju, J. Prolyl 4-hydroxylases, key enzymes in the synthesis of collagens and regulation of the response to hypoxia, and their roles as treatment targets. Ann. Med. 2008, 40, 402-417. [CrossRef] [PubMed]

51. Gilkes, D.M.; Bajpai, S.; Chaturvedi, P.; Wirtz, D.; Semenza, G.L. Hypoxia-inducible f0actor 1 (HIF-1) promotes extracellular matrix remodeling under hypoxic conditions by inducing P4HA1, P4HA2, and PLOD2 expression in fibroblasts. J. Biol. Chem. 2013, 288, 10819-10829. [CrossRef] 
52. Sada, M.; Ohuchida, K.; Horioka, K.; Okumura, T.; Moriyama, T.; Miyasaka, Y.; Ohtsuka, T.; Mizumoto, K.; Oda, Y.; Nakamura, M. Hypoxic stellate cells of pancreatic cancer stroma regulate extracellular matrix fiber organization and cancer cell motility. Cancer Lett. 2016, 372, 210-218. [CrossRef]

53. Amelio, I.; Mancini, M.; Petrova, V.; Cairns, R.A.; Vikhreva, P.; Nicolai, S.; Marini, A.; Antonov, A.A.; Le Quesne, J.; Acevedo, J.D.; et al. p53 mutants cooperate with HIF-1 in transcriptional regulation of extracellular matrix components to promote tumor progression. Proc. Natl. Acad. Sci. USA 2018, 115, E10869-E10878. [CrossRef]

54. Wong, C.C.; Gilkes, D.M.; Zhang, H.; Chen, J.; Wei, H.; Chaturvedi, P.; Fraley, S.I.; Wong, C.M.; Khoo, U.S.; Ng, I.O.; et al. Hypoxia-inducible factor 1 is a master regulator of breast cancer metastatic niche formation. Proc. Natl. Acad. Sci. USA 2011, 108, 16369-16374. [CrossRef]

55. Erler, J.T.; Bennewith, K.L.; Cox, T.R.; Lang, G.; Bird, D.; Koong, A.; Le, Q.T.; Giaccia, A.J. Hypoxia-Induced Lysyl Oxidase Is a Critical Mediator of Bone Marrow Cell Recruitment to Form the Premetastatic Niche. Cancer Cell 2009, 15, 35-44. [CrossRef] [PubMed]

56. Saatci, O.; Kaymak, A.; Raza, U.; Ersan, P.G.; Akbulut, O.; Banister, C.E.; Sikirzhytski, V.; Tokat, U.M.; Aykut, G.; Ansari, S.A.; et al. Targeting lysyl oxidase (LOX) overcomes chemotherapy resistance in triple negative breast cancer. Nat. Commun. 2020, 11, 1-17. [CrossRef]

57. Chiavarina, B.; Martinez-Outschoorn, U.E.; Whitaker-Menezes, D.; Howell, A.; Tanowitz, H.B.; Pestell, R.G.; Sotgia, F.; Lisanti, M.P. Metabolic reprogramming and two-compartment tumor metabolism: Opposing role(s) of HIF1 $\alpha$ and HIF $2 \alpha$ in tumor-associated fibroblasts and human breast cancer cells. Cell Cycle 2012, 11, 3280-3289. [CrossRef] [PubMed]

58. Becker, L.M.; O'Connell, J.T.; Vo, A.P.; Cain, M.P.; Tampe, D.; Bizarro, L.; Sugimoto, H.; McGow, A.K.; Asara, J.M.; Lovisa, S.; et al. Epigenetic Reprogramming of Cancer-Associated Fibroblasts Deregulates Glucose Metabolism and Facilitates Progression of Breast Cancer. Cell Rep. 2020, 31, 107701. [CrossRef]

59. Kugeratski, F.G.; Atkinson, S.J.; Neilson, L.J.; Lilla, S.; Knight, J.R.; Serneels, J.; Juin, A.; Ismail, S.; Bryant, D.M.; Markert, E.K.; et al. Hypoxic cancer-associated fibroblasts increase NCBP2-AS2/HIAR to promote endothelial sprouting through enhanced VEGF signaling. Sci. Signal. 2019, 12, eaan8247. [CrossRef] [PubMed]

60. Kim, J.W.; Evans, C.; Weidemann, A.; Takeda, N.; Lee, Y.S.; Stockmann, C.; Branco-Price, C.; Brandberg, F.; Leone, G.; Ostrowski, M.C.; et al. Loss of fibroblast HIF-1 $\alpha$ accelerates tumorigenesis. Cancer Res. 2012, 72, 3187-3195. [CrossRef]

61. Madsen, C.D.; Pedersen, J.T.; Venning, F.A.; Singh, L.B.; Moeendarbary, E.; Charras, G.; Cox, T.R.; Sahai, E.; Erler, J.T. Hypoxia and loss of PHD 2 inactivate stromal fibroblasts to decrease tumour stiffness and metastasis. EMBO Rep. 2015, 16, 1394-1408. [CrossRef]

62. Kim, H.J.; Cantor, H. CD4 T-cell subsets and tumor immunity: The helpful and the not-so-helpful. Cancer Immunol. Res. 2014, 2, 91-98. [CrossRef]

63. Nishimura, T.; Iwakabe, K.; Sekimoto, M.; Ohmi, Y.; Yahata, T.; Nakui, M.; Sato, T.; Habu, S.; Tashiro, H.; Sato, M.; et al. Distinct role of antigen-specific T helper type 1 (Th1) and Th2 cells in tumor eradication in vivo. J. Exp. Med. 1999, 190, 617-627. [CrossRef]

64. Ochi, A.; Nguyen, A.H.; Bedrosian, A.S.; Mushlin, H.M.; Zarbakhsh, S.; Barilla, R.; Zambirinis, C.P.; Fallon, N.C.; Rehman, A.; Pylayeva-Gupta, Y.; et al. MyD88 inhibition amplifies dendritic cell capacity to promote pancreatic carcinogenesis via Th2 cells. $J$. Exp. Med. 2012, 209, 1671-1687. [CrossRef] [PubMed]

65. Shrimali, R.K.; Yu, Z.; Theoret, M.R.; Chinnasamy, D.; Restifo, N.P.; Rosenberg, S.A. Antiangiogenic agents can increase lymphocyte infiltration into tumor and enhance the effectiveness of adoptive immunotherapy of cancer. Cancer Res. 2010, 70, 6171-6180. [CrossRef] [PubMed]

66. Tatsumi, T.; Kierstead, L.S.; Ranieri, E.; Gesualdo, L.; Schena, F.P.; Finke, J.H.; Bukowski, R.M.; Mueller-Berghaus, J.; Kirkwood, J.M.; Kwok, W.W.; et al. Disease-associated bias in T helper type 1 (Th1)/Th2 CD4+ T cell responses against MAGE-6 in HLA-DRB1*0401+ patients with renal cell carcinoma or melanoma. J. Exp. Med. 2002, 196, 619-628. [CrossRef] [PubMed]

67. Bettelli, E.; Carrier, Y.; Gao, W.; Korn, T.; Strom, T.B.; Oukka, M.; Weiner, H.L.; Kuchroo, V.K. Reciprocal developmental pathways for the generation of pathogenic effector TH17 and regulatory T cells. Nature 2006, 441, 235-238. [CrossRef]

68. Mattes, J.; Hulett, M.; Xie, W.; Hogan, S.; Rothenberg, M.E.; Foster, P.; Parish, C. Immunotherapy of cytotoxic T cell-resistant tumors by T helper 2 cells: An eotaxin and STAT6-dependent process. J. Exp. Med. 2003, 197, 387-393. [CrossRef]

69. Vignali, D.A.A.; Collison, L.W.; Workman, C.J. How regulatory T cells work. Nat. Rev. Immunol. 2008, 8, 523-532. [CrossRef]

70. Nakamura, H.; Makino, Y.; Okamoto, K.; Poellinger, L.; Ohnuma, K.; Morimoto, C.; Tanaka, H. TCR Engagement Increases Hypoxia-Inducible Factor- $1 \alpha$ Protein Synthesis via Rapamycin-Sensitive Pathway under Hypoxic Conditions in Human Peripheral T Cells. J. Immunol. 2005, 174, 7592-7599. [CrossRef]

71. Palazon, A.; Goldrath, A.W.; Nizet, V.; Johnson, R.S. HIF Transcription Factors, Inflammation, and Immunity. Immunity 2014, 41, 518-528. [CrossRef] [PubMed]

72. Shehade, H.; Acolty, V.; Moser, M.; Oldenhove, G. Cutting Edge: Hypoxia-Inducible Factor 1 Negatively Regulates Th1 Function. J. Immunol. 2015, 195, 1372-1376. [CrossRef]

73. Facciabene, A.; Peng, X.; Hagemann, I.S.; Balint, K.; Barchetti, A.; Wang, L.P.; Gimotty, P.A.; Gilks, C.B.; Lal, P.; Zhang, L.; et al. Tumour hypoxia promotes tolerance and angiogenesis via CCL28 and T(reg) cells. Nature 2011, 475, 226-230. [CrossRef]

74. Dang, E.V.; Barbi, J.; Yang, H.Y.; Jinasena, D.; Yu, H.; Zheng, Y.; Bordman, Z.; Fu, J.; Kim, Y.; Yen, H.R.; et al. Control of TH17/Treg balance by hypoxia-inducible factor 1 . Cell 2011, 146, 772-784. [CrossRef] 
75. Darce, J.; Rudra, D.; Li, L.; Nishio, J.; Cipolletta, D.; Rudensky, A.Y.; Mathis, D.; Benoist, C. An N-Terminal Mutation of the Foxp3 Transcription Factor Alleviates Arthritis but Exacerbates Diabetes. Immunity 2012, 36, 731-741. [CrossRef]

76. Shi, L.Z.; Wang, R.; Huang, G.; Vogel, P.; Neale, G.; Green, D.R.; Chi, H. HIF1 $\alpha$-dependent glycolytic pathway orchestrates a metabolic checkpoint for the differentiation of TH17 and Treg cells. J. Exp. Med. 2011, 208, 1367-1376. [CrossRef] [PubMed]

77. Lee, J.H.; Elly, C.; Park, Y.; Liu, Y.C. E3Ubiquitin Ligase VHL Regulates Hypoxia-Inducible Factor-1 $\alpha$ to Maintain Regulatory T Cell Stability and Suppressive Capacity. Immunity 2015, 42, 1062-1074. [CrossRef]

78. Ben-Shoshan, J.; Maysel-Auslender, S.; Mor, A.; Keren, G.; George, J. Hypoxia controls CD4+ CD25+ regulatory T-cell homeostasis via hypoxia-inducible factor-1 $\alpha$. Eur. J. Immunol. 2008, 38, 2412-2418. [CrossRef] [PubMed]

79. Clambey, E.T.; McNamee, E.N.; Westrich, J.A.; Glover, L.E.; Campbell, E.L.; Jedlicka, P.; de Zoeten, E.F.; Cambier, J.C.; Stenmark, K.R.; Colgan, S.P.; et al. Hypoxia-inducible factor-1 alpha-dependent induction of FoxP3 drives regulatory T-cell abundance and function during inflammatory hypoxia of the mucosa. Proc. Natl. Acad. Sci. USA 2012, 109, E2784-E2793. [CrossRef] [PubMed]

80. Westendorf, A.M.; Skibbe, K.; Adamczyk, A.; Buer, J.; Geffers, R.; Hansen, W.; Pastille, E.; Jendrossek, V. Hypoxia enhances immunosuppression by inhibiting CD4+ Effector T cell function and promoting treg activity. Cell. Physiol. Biochem. 2017, 41, 1271-1284. [CrossRef] [PubMed]

81. Hsu, T.S.; Lin, Y.L.; Wang, Y.A.; Mo, S.T.; Chi, P.Y.; Lai, A.C.; Pan, H.Y.; Chang, Y.J.; Lai, M.Z. HIF-2 $\alpha$ is indispensable for regulatory T cell function. Nat. Commun. 2020, 11, 1-16. [CrossRef] [PubMed]

82. Chen, D.S.; Mellman, I. Oncology meets immunology: The cancer-immunity cycle. Immunity 2013, 39, 1-10. [CrossRef]

83. Vantourout, P.; Hayday, A. Six-of-the-best: Unique contributions of $\gamma \delta$ T cells to immunology. Nat. Rev. Immunol. 2013, 13, 88-100. [CrossRef] [PubMed]

84. Doedens, A.L.; Phan, A.T.; Stradner, M.H.; Fujimoto, J.K.; Nguyen, J.V.; Yang, E.; Johnson, R.S.; Goldrath, A.W. Hypoxia-inducible factors enhance the effector responses of CD8 + T cells to persistent antigen. Nat. Immunol. 2013, 14, 1173-1182. [CrossRef]

85. Palazón, A.; Martínez-Forero, I.; Teijeira, A.; Morales-Kastresana, A.; Alfaro, C.; Sanmamed, M.F.; Perez-Gracia, J.L.; Peñuelas, I.; Hervás-Stubbs, S.; Rouzaut, A.; et al. The HIF-1 $\alpha$ hypoxia response in tumor-infi ltrating T lymphocytes induces functional CD137 (4-1BB) for immunotherapy. Cancer Discov. 2012, 2, 608-623. [CrossRef] [PubMed]

86. Caldwell, C.C.; Kojima, H.; Lukashev, D.; Armstrong, J.; Farber, M.; Apasov, S.G.; Sitkovsky, M.V. Differential Effects of Physiologically Relevant Hypoxic Conditions on T Lymphocyte Development and Effector Functions. J. Immunol. 2001, 167, 6140-6149. [CrossRef]

87. de Almeida, P.E.; Mak, J.; Hernandez, G.; Jesudason, R.; Herault, A.; Javinal, V.; Borneo, J.; Kim, J.M.; Walsh, K.B. Anti-VEGF Treatment Enhances CD8+ T-Cell Antitumor Activity by Amplifying Hypoxia. Cancer Immunol. Res. 2020, 8, 806-818. [CrossRef] [PubMed]

88. Gropper, Y.; Feferman, T.; Shalit, T.; Salame, T.M.; Porat, Z.; Shakhar, G. Culturing CTLs under Hypoxic Conditions Enhances Their Cytolysis and Improves Their Anti-tumor Function. Cell Rep. 2017, 20, 2547-2555. [CrossRef]

89. Palazon, A.; Tyrakis, P.A.; Macias, D.; Veliça, P.; Rundqvist, H.; Fitzpatrick, S.; Vojnovic, N.; Phan, A.T.; Loman, N.; Hedenfalk, I.; et al. An HIF-1 $\alpha$ /VEGF-A Axis in Cytotoxic T Cells Regulates Tumor Progression. Cancer Cell. 2017, 32, 669-683. [CrossRef] [PubMed]

90. Finlay, D.K.; Rosenzweig, E.; Sinclair, L.V.; Feijoo-Carnero, C.; Hukelmann, J.L.; Rolf, J.; Panteleyev, A.A.; Okkenhaug, K.; Cantrell, D.A. PDK1 regulation of $\mathrm{mTOR}$ and hypoxia-inducible factor 1 integrate metabolism and migration of CD8+ T cells. J. Exp. Med. 2012, 209, 2441-2453. [CrossRef] [PubMed]

91. Thiel, M.; Caldwell, C.C.; Kreth, S.; Kuboki, S.; Chen, P.; Smith, P.; Ohta, A.; Lentsch, A.B.; Lukashev, D.; Sitkovsky, M.V. Targeted deletion of HIF-1alpha gene in T cells prevents their inhibition in hypoxic inflamed tissues and improves septic mice survival. PLoS One 2007, 2, e853. [CrossRef]

92. Lukashev, D.; Klebanov, B.; Kojima, H.; Grinberg, A.; Ohta, A.; Berenfeld, L.; Wenger, R.H.; Ohta, A.; Sitkovsky, M. Cutting Edge: Hypoxia-Inducible Factor $1 \alpha$ and Its Activation-Inducible Short Isoform I.1 Negatively Regulate Functions of CD4 + and CD8 + T Lymphocytes. J. Immunol. 2006, 177, 4962-4965. [CrossRef] [PubMed]

93. Liu, Y.N.; Yang, J.F.; Huang, D.J.; Ni, H.H.; Zhang, C.X.; Zhang, L.; He, J.; Gu, J.M.; Chen, H.X.; Mai, H.Q.; et al. Hypoxia Induces Mitochondrial Defect That Promotes T Cell Exhaustion in Tumor Microenvironment Through MYC-Regulated Pathways. Front. Immunol. 2020, 11, 1906. [CrossRef] [PubMed]

94. Najjar, Y.G.; Menk, A.V.; Sander, C.; Rao, U.; Karunamurthy, A.; Bhatia, R.; Zhai, S.; Kirkwood, J.M.; Delgoffe, G.M. Tumor cell oxidative metabolism as a barrier to PD-1 blockade immunotherapy in melanoma. JCI Insight 2019, 4, e124989. [CrossRef] [PubMed]

95. Mantovani, A.; Marchesi, F.; Malesci, A.; Laghi, L.; Allavena, P. Tumour-associated macrophages as treatment targets in oncology. Nat. Rev. Clin. Oncol. 2017, 14, 399-416. [CrossRef] [PubMed]

96. Allavena, P.; Mantovani, A. Immunology in the clinic review series; focus on cancer: Tumour-associated macrophages: Undisputed stars of the inflammatory tumour microenvironment. Clin. Exp. Immunol. 2012, 167, 195-205. [CrossRef]

97. Albini, A.; Bruno, A.; Noonan, D.M.; Mortara, L. Contribution to tumor angiogenesis from innate immune cells within the tumor microenvironment: Implications for immunotherapy. Front. Immunol. 2018, 9, 527. [CrossRef]

98. Henze, A.-T.; Mazzone, M. The impact of hypoxia on tumor-associated macrophages. J. Clin. Investig. 2016, 126, 3672-3679. [CrossRef] 
99. Biswas, S.K.; Sica, A.; Lewis, C.E. Plasticity of Macrophage Function during Tumor Progression: Regulation by Distinct Molecular Mechanisms. J. Immunol. 2008, 180, 2011-2017. [CrossRef]

100. Du, R.; Lu, K.V.; Petritsch, C.; Liu, P.; Ganss, R.; Passegué, E.; Song, H.; VandenBerg, S.; Johnson, R.S.; Werb, Z.; et al. HIF1 $\alpha$ Induces the Recruitment of Bone Marrow-Derived Vascular Modulatory Cells to Regulate Tumor Angiogenesis and Invasion. Cancer Cell. 2008, 13, 206-220. [CrossRef]

101. Casazza, A.; Laoui, D.; Wenes, M.; Rizzolio, S.; Bassani, N.; Mambretti, M.; Deschoemaeker, S.; Van Ginderachter, J.A.; Tamagnone, L.; Mazzone, M. Impeding Macrophage Entry into Hypoxic Tumor Areas by Sema3A/Nrp1 Signaling Blockade Inhibits Angiogenesis and Restores Antitumor Immunity. Cancer Cell 2013, 24, 695-709. [CrossRef]

102. Murdoch, C.; Giannoudis, A.; Lewis, C.E. Mechanisms regulating the recruitment of macrophages into hypoxic areas of tumors and other ischemic tissues. Blood 2004, 104, 2224-2234. [CrossRef]

103. Guo, X.; Xue, H.; Shao, Q.; Wang, J.; Guo, X.; Chen, X.; Zhang, J.; Xu, S.; Li, T.; Zhang, P.; et al. Hypoxia promotes glioma-associated macrophage infiltration via periostin and subsequent M2 polarization by upregulating TGF-beta and M-CSFR. Oncotarget 2016, 7, 80521-80542. [CrossRef]

104. Hughes, R.; Qian, B.Z.; Rowan, C.; Muthana, M.; Keklikoglou, I.; Olson, O.C.; Tazzyman, S.; Danson, S.; Addison, C.; Clemons, M.; et al. Perivascular M2 macrophages stimulate tumor relapse after chemotherapy. Cancer Res. 2015, 75, 3479-3491. [CrossRef]

105. Doedens, A.L.; Stockmann, C.; Rubinstein, M.P.; Liao, D.; Zhang, N.; DeNardo, D.G.; Coussens, L.M.; Karin, M.; Goldrath, A.W.; Johnson, R.S. Macrophage expression of hypoxia-inducible factor- $1 \alpha$ suppresses T-cell function and promotes tumor progression. Cancer Res. 2010, 70, 7465-7475. [CrossRef] [PubMed]

106. Ye, L.Y.; Chen, W.; Bai, X.L.; Xu, X.Y.; Zhang, Q.; Xia, X.F.; Sun, X.; Li, G.G.; Hu, Q.D.; Fu, Q.H.; et al. Hypoxia-Induced Epithelial-to-Mesenchymal Transition in Hepatocellular Carcinoma Induces an Immunosuppressive Tumor Microenvironment to Promote Metastasis. Cancer Res. 2016, 76, 818-830. Available online: http://cancerres.aacrjournals.org/content/76/4/818.long (accessed on 1 August 2017). [CrossRef]

107. Imtiyaz, H.Z.; Williams, E.P.; Hickey, M.M.; Patel, S.A.; Durham, A.C.; Yuan, L.J.; Hammond, R.; Gimotty, P.A.; Keith, B.; Simon, M.C. Hypoxia-inducible factor $2 \alpha$ regulates macrophage function in mouse models of acute and tumor inflammation. J. Clin. Investig. 2010, 120, 2699-2714. [CrossRef] [PubMed]

108. Burke, B.; Giannoudis, A.; Corke, K.P.; Gill, D.; Wells, M.; Ziegler-Heitbrock, L.; Lewis, C.E. Hypoxia-induced gene expression in human macrophages: Implications for ischemic tissues and hypoxia-regulated gene therapy. Am. J. Pathol. 2003, 163, 1233-1243. [CrossRef]

109. White, J.R.; Harris, R.A.; Lee, S.R.; Craigon, M.H.; Binley, K.; Price, T.; Beard, G.L.; Mundy, C.R.; Naylor, S. Genetic amplification of the transcriptional response to hypoxia as a novel means of identifying regulators of angiogenesis. Genomics 2004, 83, 1-8. [CrossRef]

110. Werno, C.; Menrad, H.; Weigert, A.; Dehne, N.; Goerdt, S.; Schledzewski, K.; Kzhyshkowska, J.; Brüne, B. Knockout of HIF-1 $\alpha$ in tumor-associated macrophages enhances M2 polarization and attenuates their pro-angiogenic responses. Carcinogenesis 2010, 31, 1863-1872. [CrossRef] [PubMed]

111. Strowitzki, M.J.; Ritter, A.S.; Radhakrishnan, P.; Harnoss, J.M.; Opitz, V.M.; Biller, M.; Wehrmann, J.; Keppler, U.; Scheer, J.; Wallwiener, M.; et al. Pharmacological HIF-inhibition attenuates postoperative adhesion formation. Sci. Rep. 2017, 7, 1-14. [CrossRef]

112. Strowitzki, M.J.; Kimmer, G.; Wehrmann, J.; Ritter, A.S.; Radhakrishnan, P.; Opitz, V.M.; Tuffs, C.; Biller, M.; Kugler, J.; Keppler, U.; et al. Inhibition of HIF-prolyl hydroxylases improves healing of intestinal anastomoses. JCI Insight 2021, 6, e139191. [CrossRef]

113. Gabrilovich, D.I.; Nagaraj, S. Myeloid-derived suppressor cells as regulators of the immune system. Nat. Rev. Immunol. 2009, 9, 162-174. [CrossRef] [PubMed]

114. Gabrilovich, D.I.; Ostrand-Rosenberg, S.; Bronte, V. Coordinated regulation of myeloid cells by tumours. Nat. Rev. Immunol. 2012, 12, 253-268. [CrossRef]

115. Pan, P.Y.; Ma, G.; Weber, K.J.; Ozao-Choy, J.; Wang, G.; Yin, B.; Divino, C.M.; Chen, S.H. Immune stimulatory receptor CD40 is required for T-cell suppression and $\mathrm{T}$ regulatory cell activation mediated by myeloid-derived suppressor cells in cancer. Cancer Res. 2010, 70, 99-108. [CrossRef] [PubMed]

116. Srivastava, M.K.; Sinha, P.; Clements, V.K.; Rodriguez, P.; Ostrand-Rosenberg, S. Myeloid-derived suppressor cells inhibit T-cell activation by depleting cystine and cysteine. Cancer Res. 2010, 70, 68-77. [CrossRef]

117. Chiu, D.K.; Xu, I.M.; Lai, R.K.; Tse, A.P.; Wei, L.L.; Koh, H.Y.; Li, L.L.; Lee, D.; Lo, R.C.; Wong, C.M.; et al. Hypoxia induces myeloid-derived suppressor cell recruitment to hepatocellular carcinoma through chemokine (C-C motif) ligand 26. Hepatology 2016, 64, 797-813. [CrossRef]

118. Corzo, C.A.; Condamine, T.; Lu, L.; Cotter, M.J.; Youn, J.I.; Cheng, P.; Cho, H.I.; Celis, E.; Quiceno, D.G.; Padhya, T.; et al. HIF-1 $\alpha$ regulates function and differentiation of myeloid-derived suppressor cells in the tumor microenvironment. J. Exp. Med. 2010, 207, 2439-2453. [CrossRef] [PubMed]

119. Noman, M.Z.; Desantis, G.; Janji, B.; Hasmim, M.; Karray, S.; Dessen, P.; Bronte, V.; Chouaib, S. PD-L1 is a novel direct target of HIF-1 $\alpha$, and its blockade under hypoxia enhanced: MDSC-mediated T cell activation. J. Exp. Med. 2014, 211, 781-790. [CrossRef] [PubMed]

120. Noman, M.Z.; Janji, B.; Hu, S.; Wu, J.C.; Martelli, F.; Bronte, V.; Chouaib, S. Tumor-promoting effects of myeloid-derived suppressor cells are potentiated by hypoxia-induced expression of miR-210. Cancer Res. 2015, 75, 3771-3787. [CrossRef] 
121. Deng, J.; Li, J.; Sarde, A.; Lines, J.L.; Lee, Y.C.; Qian, D.C.; Pechenick, D.A.; Manivanh, R.; Le Mercier, I.; Lowrey, C.H.; et al. Hypoxia-induced VISTA promotes the suppressive function of myeloid-derived suppressor cells in the tumor microenvironment. Cancer Immunol. Res. 2019, 7, 1079-1090. [CrossRef] [PubMed]

122. Qian, X.; Zhang, Q.; Shao, N.; Shan, Z.; Cheang, T.; Zhang, Z.; Su, Q.; Wang, S.; Lin, Y. Respiratory hyperoxia reverses immunosuppression by regulating myeloid-derived suppressor cells and PD-L1 expression in a triple-negative breast cancer mouse model. Am. J. Cancer Res. 2019, 9, 529-545. Available online: http:/ / www.ncbi.nlm.nih.gov/pubmed/30949408 (accessed on 4 February 2021). [PubMed]

123. Tan, J.K.H.; O'Neill, H.C. Maturation requirements for dendritic cells in T cell stimulation leading to tolerance versus immunity. J. Leukoc. Biol. 2005, 78, 319-324. [CrossRef] [PubMed]

124. Lutz, M.B.; Schuler, G. Immature, semi-mature and fully mature dendritic cells: Which signals induce tolerance or immunity? Trends Immunol. 2002, 23, 445-449. [CrossRef]

125. Bellone, G.; Carbone, A.; Smirne, C.; Scirelli, T.; Buffolino, A.; Novarino, A.; Stacchini, A.; Bertetto, O.; Palestro, G.; Sorio, C.; et al. Cooperative Induction of a Tolerogenic Dendritic Cell Phenotype by Cytokines Secreted by Pancreatic Carcinoma Cells J. Immunol. 2006, 177, 3448-3460. [CrossRef]

126. Gabrilovich, D. Mechanisms and functional significance of tumour-induced dendritic-cell defects. Nat. Rev. Immunol. 2004, 4, 941-952. [CrossRef]

127. Ghiringhelli, F.; Puig, P.E.; Roux, S.; Parcellier, A.; Schmitt, E.; Solary, E.; Kroemer, G.; Martin, F.; Chauffert, B.; Zitvogel, L. Tumor cells convert immature myeloid dendritic cells into TGF- $\beta$-secreting cells inducing CD4 +CD25+ regulatory T cell proliferation. J. Exp. Med. 2005, 202, 919-929. [CrossRef]

128. Filippi, I.; Morena, E.; Aldinucci, C.; Carraro, F.; Sozzani, S.; Naldini, A. Short-Term hypoxia enhances the migratory capability of dendritic cell through HIF-1 $\alpha$ and PI3K/Akt pathway. J. Cell Physiol. 2014, 229, 2067-2076. [CrossRef]

129. Köhler, T.; Reizis, B.; Johnson, R.S.; Weighardt, H.; Förster, I. Influence of hypoxia-inducible factor $1 \alpha$ on dendritic cell differentiation and migration. Eur. J. Immunol. 2012, 42, 1226-1236. [CrossRef]

130. Jantsch, J.; Chakravortty, D.; Turza, N.; Prechtel, A.T.; Buchholz, B.; Gerlach, R.G.; Volke, M.; Gläsner, J.; Warnecke, C.; Wiesener, M.S.; et al. Hypoxia and Hypoxia-Inducible Factor- $1 \alpha$ Modulate Lipopolysaccharide-Induced Dendritic Cell Activation and Function. J. Immunol. 2008, 180, 4697-4705. [CrossRef]

131. Bosco, M.C.; Pierobon, D.; Blengio, F.; Raggi, F.; Vanni, C.; Gattorno, M.; Eva, A.; Novelli, F.; Cappello, P.; Giovarelli, M.; et al. Hypoxia modulates the gene expression profile of immunoregulatory receptors in human mature dendritic cells: Identification of TREM-1 as a novel hypoxic marker in vitro and in vivo. Blood 2011, 117, 2625-2639. [CrossRef] [PubMed]

132. Pierobon, D.; Bosco, M.C.; Blengio, F.; Raggi, F.; Eva, A.; Filippi, M.; Musso, T.; Novelli, F.; Cappello, P.; Varesio, L.; et al. Chronic hypoxia reprograms human immature dendritic cells by inducing a proinflammatory phenotype and TREM-1 expression. Eur. J. Immunol. 2013, 43, 949-966. [CrossRef]

133. Bouchon, A.; Dietrich, J.; Colonna, M. Cutting Edge: Inflammatory Responses Can Be Triggered by TREM-1, a Novel Receptor Expressed on Neutrophils and Monocytes. J. Immunol. 2000, 164, 4991-4995. [CrossRef]

134. Ogino, T.; Onishi, H.; Suzuki, H.; Morisaki, T.; Tanaka, M.; Katano, M. Inclusive estimation of complex antigen presentation functions of monocyte-derived dendritic cells differentiated under normoxia and hypoxia conditions. Cancer Immunol. Immunother. 2012, 61, 409-424. [CrossRef]

135. Naldini, A.; Morena, E.; Pucci, A.; Miglietta, D.; Riboldi, E.; Sozzani, S.; Carraro, F. Hypoxia affects dendritic cell survival: Role of the hypoxia-inducible factor-1 $\alpha$ and lipopolysaccharide. J. Cell. Physiol. 2012, 227, 587-595. [CrossRef]

136. Yang, M.; Liu, Y.; Ren, G.; Shao, Q.; Gao, W.; Sun, J.; Wang, H.; Ji, C.; Li, X.; Zhang, Y.; et al. Increased expression of surface CD44 in hypoxia-DCs skews helper T cells toward a Th2 polarization. Sci. Rep. 2015, 5, 1-12. [CrossRef]

137. Tran, C.W.; Gold, M.J.; Garcia-Batres, C.; Tai, K.; Elford, A.R.; Himmel, M.E.; Elia, A.J.; Ohashi, P.S. Hypoxia-inducible factor 1 alpha limits dendritic cell stimulation of CD8 T cell immunity. PLoS ONE 2020, 15, e0244366. [CrossRef] [PubMed]

138. Kheshtchin, N.; Arab, S.; Ajami, M.; Mirzaei, R.; Ashourpour, M.; Mousavi, N.; Khosravianfar, N.; Jadidi-Niaragh, F.; Namdar, A.; Noorbakhsh, F; i et al. Inhibition of HIF-1 $\alpha$ enhances anti-tumor effects of dendritic cell-based vaccination in a mouse model of breast cancer. Cancer Immunol. Immunother. 2016, 65, 1159-1167. [CrossRef] [PubMed]

139. Zhou, M.; Xie, Y.; Xu, S.; Xin, J.; Wang, J.; Han, T.; Ting, R.; Zhang, J.; An, F. Hypoxia-activated nanomedicines for effective cancer therapy. Eur. J. Med. Chem. 2020, 195, 112274. [CrossRef]

140. Doherty, N.; Hancock, S.L.; Kaye, S.; Coleman, C.N.; Shulman, L.; Marquez, C.; Mariscal, C.; Rampling, R.; Senan, S.; Roemeling, R.V. Muscle cramping in phase i clinical trials of tirapazamine (SR 4233) with and without radiation. Int. J. Radiat. Oncol. 1994, 29, 379-382. [CrossRef]

141. Baran, N.; Konopleva, M. Molecular pathways: Hypoxia-activated prodrugs in cancer therapy. Clin. Cancer Res. 2017, 23, 2382-2390. [CrossRef]

142. Spiegelberg, L.; Houben, R.; Niemans, R.; de Ruysscher, D.; Yaromina, A.; Theys, J.; Guise, C.P.; Smaill, J.B.; Patterson, A.V.; Lambin, P.; et al. Hypoxia-activated prodrugs and (lack of) clinical progress: The need for hypoxia-based biomarker patient selection in phase III clinical trials. Clin. Transl. Radiat. Oncol. 2019, 15, 62-69. [CrossRef]

143. Liapis, V.; Labrinidis, A.; Zinonos, I.; Hay, S.; Ponomarev, V.; Panagopoulos, V.; DeNichilo, M.; Ingman, W.; Atkins, G.J.; Findlay, D.M.; et al. Hypoxia-activated pro-drug TH-302 exhibits potent tumor suppressive activity and cooperates with chemotherapy against osteosarcoma. Cancer Lett. 2015, 357, 160-169. [CrossRef] 
144. Liu, Q.; Sun, J.D.; Wang, J.; Ahluwalia, D.; Baker, A.F.; Cranmer, L.D.; Ferraro, D.; Wang, Y.; Duan, J.X.; Ammons, W.S.; et al. TH-302, a hypoxia-activated prodrug with broad in vivo preclinical combination therapy efficacy: Optimization of dosing regimens and schedules. Cancer Chemother. Pharmacol. 2012, 69, 1487-1498. [CrossRef]

145. Lohse, I.; Rasowski, J.; Cao, P.; Pintilie, M.; Do, T.; Tsao, M.S.; Hill, R.P.; Hedley, D.W. Targeting hypoxic microenvironment of pancreatic xenografts with the hypoxia-activated prodrug TH-302. Oncotarget 2016, 7, 33571-33580. [CrossRef]

146. Saggar, J.K.; Tannock, I.F. Chemotherapy Rescues Hypoxic Tumor Cells and Induces Their Reoxygenation and Repopulation-An Effect That Is Inhibited by the Hypoxia-Activated Prodrug TH-302. Clin. Cancer Res. 2015, 21, 2107-2114. [CrossRef]

147. Peeters, S.G.; Zegers, C.M.; Biemans, R.; Lieuwes, N.G.; van Stiphout, R.G.; Yaromina, A.; Sun, J.D.; Hart, C.P.; Windhorst, A.D.; van Elmpt, W.; et al. TH-302 in Combination with Radiotherapy Enhances the Therapeutic Outcome and Is Associated with Pretreatment [18 F]HX4 Hypoxia PET Imaging. Clin. Cancer Res. 2015, 21, 2984-2992. [CrossRef]

148. Zhang, L.; Marrano, P.; Wu, B.; Kumar, S.; Thorner, P.; Baruchel, S. Combined Antitumor Therapy with Metronomic Topotecan and Hypoxia-Activated Prodrug, Evofosfamide, in Neuroblastoma and Rhabdomyosarcoma Preclinical Models. Clin. Cancer Res. 2016, 22, 2697-2708. [CrossRef]

149. Codony, V.L.; Tavassoli, M. Hypoxia-induced therapy resistance: Available hypoxia-targeting strategies and current advances in head and neck cancer. Transl. Oncol. 2021, 14, 101017. [CrossRef]

150. Hunter, F.W.; Wouters, B.G.; Wilson, W.R. Hypoxia-activated prodrugs: Paths forward in the era of personalised medicine. Br. J. Cancer. 2016, 114, 1071-1077. [CrossRef]

151. Wigerup, C.; Påhlman, S.; Bexell, D. Therapeutic targeting of hypoxia and hypoxia-inducible factors in cancer. Pharmacol. Ther. 2016, 164, 152-169. [CrossRef]

152. Albadari, N.; Deng, S.; Li, W. The transcriptional factors HIF-1 and HIF-2 and their novel inhibitors in cancer therapy. Expert Opin. Drug Discov. 2019, 14, 667-682. [CrossRef]

153. Eliasof, S.; Lazarus, D.; Peters, C.G.; Case, R.I.; Cole, R.O.; Hwang, J.; Schluep, T.; Chao, J.; Lin, J.; Yen, Y.; et al. Correlating preclinical animal studies and human clinical trials of a multifunctional, polymeric nanoparticle. Proc. Natl. Acad. Sci. USA 2013, 110, 15127-15132. [CrossRef]

154. Pham, E.; Yin, M.; Peters, C.G.; Lee, C.R.; Brown, D.; Xu, P.; Man, S.; Jayaraman, L.; Rohde, E.; Chow, A.; et al. Preclinical Efficacy of Bevacizumab with CRLX101, an Investigational Nanoparticle-Drug Conjugate, in Treatment of Metastatic Triple-Negative Breast Cancer. Cancer Res. 2016, 76, 4493-4503. [CrossRef]

155. Lin, C.-J.; Lin, Y.-L.; Luh, F.; Yen, Y.; Chen, R.-M. Preclinical effects of CRLX101, an investigational camptothecin-containing nanoparticle drug conjugate, on treating glioblastoma multiforme via apoptosis and antiangiogenesis. Oncotarget 2016, 7, 42408-42421. [CrossRef]

156. Schluep, T.; Hwang, J.; Cheng, J.; Heidel, J.D.; Bartlett, D.W.; Hollister, B.; Davis, M.E. Preclinical Efficacy of the CamptothecinPolymer Conjugate IT-101 in Multiple Cancer Models. Clin. Cancer Res. 2006, 12, 1606-1614. [CrossRef]

157. Lu, J.; Li, Z.; Zink, J.I.; Tamanoi, F. In vivo tumor suppression efficacy of mesoporous silica nanoparticles-based drug-delivery system: Enhanced efficacy by folate modification. Nanomed. Nanotechnol. Biol. Med. 2012, 8, 212-220. [CrossRef]

158. Schmidt, K.T.; Chau, C.H.; Strope, J.D.; Huitema, A.D.; Sissung, T.M.; Price, D.K.; Figg, W.D. Antitumor activity of NLG207 (formerly CRLX101) in combination with enzalutamide in preclinical prostate cancer models. Mol. Cancer Ther. 2021, 20, 915-924. [CrossRef]

159. Krasner, C.N.; Birrer, M.J.; Berlin, S.T.; Horowitz, N.S.; Buss, M.K.; Eliasof, S.; Garmey, E.G.; Hennessy, M.G.; Konstantinopoulos, P.; Matulonis, U. Phase II clinical trial evaluating CRLX101 in recurrent ovarian, tubal, and peritoneal cancer. J. Clin. Oncol. 2014, 32, 5581. [CrossRef]

160. Xie, C.; Gao, X.; Sun, D.; Zhang, Y.; Krausz, K.W.; Qin, X.; Gonzalez, F.J. Metabolic profiling of the novel hypoxia-inducible factor $2 \alpha$ inhibitor PT2385 in vivo and in vitro. Drug Metab. Dispos. 2018, 46, 336-345. [CrossRef]

161. Chen, W.; Hill, H.; Christie, A.; Kim, M.S.; Holloman, E.; Pavia-Jimenez, A.; Homayoun, F.; Ma, Y.; Patel, N.; Yell, P.; et al. Targeting renal cell carcinoma with a HIF-2 antagonist. Nature 2016, 539, 112-117. [CrossRef]

162. Strowd, R.E.; Ellingson, B.M.; Wen, P.Y.; Ahluwalia, M.S.; Piotrowski, A.F.; Desai, A.S.; Clarke, J.L.; Lieberman, F.S.; Desideri, S.; Nabors, L.B.; et al. Safety and activity of a first-in-class oral HIF2-alpha inhibitor, PT2385, in patients with first recurrent glioblastoma (GBM). J. Clin. Oncol. 2019, 37, 2027. [CrossRef]

163. Fallah, J.; Rini, B.I. HIF Inhibitors: Status of Current Clinical Development. Curr. Oncol. Rep. 2019, 21, 6. [CrossRef]

164. Land, S.C.; Tee, A.R. Hypoxia-inducible Factor $1 \alpha$ Is Regulated by the Mammalian Target of Rapamycin (mTOR) via an mTOR Signaling Motif. J. Biol. Chem. 2007, 282, 20534-20543. [CrossRef]

165. Bohan, P.M.; Chick, R.C.; O’Shea, A.E.; Vreeland, T.J.; Hickerson, A.T.; Cindass, J.L.; Ensley, D.C.; Hale, D.; Clifton, G.T.; Sohn, V.Y.; et al. Phase I Trial of Encapsulated Rapamycin in Patients with Prostate Cancer Under Active Surveillance to Prevent Progression. Cancer Prev. Res. 2021, 14, 551-562. [CrossRef]

166. Ugwueze, C.V.; Ogamba, O.J.; Young, E.E.; Onyenekwe, B.M.; Ezeokpo, B.C. Metformin: A Possible Option in Cancer Chemotherapy. Anal. Cell. Pathol. 2020, 2020, 7180923. [CrossRef]

167. Scharping, N.E.; Menk, A.V.; Whetstone, R.D.; Zeng, X.; Delgoffe, G.M. Efficacy of PD-1 blockade is potentiated by metformininduced reduction of tumor hypoxia. Cancer Immunol. Res. 2017, 5, 9-16. [CrossRef] [PubMed]

168. Banerjee, S.; Saluja, A. Minnelide, a novel drug for pancreatic and liver cancer. Pancreatology 2015, 15, S39-S43. [CrossRef] 
169. Chouaib, S.; Noman, M.Z.; Kosmatopoulos, K.; Curran, M.A. Hypoxic stress: Obstacles and opportunities for innovative immunotherapy of cancer. Oncogene 2017, 36, 439-445. [CrossRef] [PubMed]

170. Jayaprakash, P.; Ai, M.; Liu, A.; Budhani, P.; Bartkowiak, T.; Sheng, J.; Ager, C.; Nicholas, C.; Jaiswal, A.R.; Sun, Y.; et al. Targeted hypoxia reduction restores $\mathrm{T}$ cell infiltration and sensitizes prostate cancer to immunotherapy. J. Clin. Investig. 2018, 128, 5137-5149. [CrossRef]

171. Dewhirst, M.W.; Mowery, Y.M.; Mitchell, J.B.; Cherukuri, M.K.; Secomb, T.W. Rationale for hypoxia assessment and amelioration for precision therapy and immunotherapy studies. J. Clin. Investig. 2019, 129, 489-491. [CrossRef] [PubMed]

172. Rapisarda, A.; Melillo, G. Overcoming disappointing results with antiangiogenic therapy by targeting hypoxia. Nat. Rev. Clin. Oncol. 2012, 9, 378-390. [CrossRef] [PubMed]

173. Shang, B.; Cao, Z.; Zhou, Q. Progress in tumor vascular normalization for anticancer therapy: Challenges and perspectives. Front. Med. 2012, 6, 67-78. [CrossRef] [PubMed]

174. Yoon, C.; Lee, H.J.; Park, D.J.; Lee, Y.J.; Tap, W.D.; Eisinger-Mathason, T.S.; Hart, C.P.; Choy, E.; Simon, M.C.; Yoon, S.S. Hypoxiaactivated chemotherapeutic TH-302 enhances the effects of VEGF-A inhibition and radiation on sarcomas. Br. J. Cancer 2015, 113, 46-56. [CrossRef] [PubMed]

175. Liu, S.; Tetzlaff, M.T.; Wang, T.; Chen, X.; Yang, R.; Kumar, S.M.; Vultur, A.; Li, P.; Martin, J.S.; Herlyn, M.; et al. Hypoxia-activated prodrug enhances therapeutic effect of sunitinib in melanoma. Oncotarget 2017, 8, 115140. [CrossRef]

176. Kumar, S.; Sun, J.D.; Zhang, L.; Mokhtari, R.B.; Wu, B.; Meng, F.; Liu, Q.; Bhupathi, D.; Wang, Y.; Yeger, H.; et al. HypoxiaTargeting Drug Evofosfamide (TH-302) Enhances Sunitinib Activity in Neuroblastoma Xenograft Models. Transl. Oncol. 2018, 11, 911-919. [CrossRef] [PubMed]

177. Brenner, A.J.; Floyd, J.; Fichtel, L.; Michalek, J.; Kanakia, K.P.; Huang, S.; Reardon, D.; Wen, P.Y.; Lee, E.Q. Phase 2 trial of hypoxia activated evofosfamide (TH302) for treatment of recurrent bevacizumab-refractory glioblastoma. Sci. Rep. 2021, 11, 2306. [CrossRef] [PubMed]

178. Meaney, C.; Rhebergen, S.; Kohandel, M. In silico analysis of hypoxia activated prodrugs in combination with anti angiogenic therapy through nanocell delivery. PLoS Comput. Biol. 2020, 16, e1007926. [CrossRef] [PubMed]

179. Fjeldbo, C.S.; Hompland, T.; Hillestad, T.; Aarnes, E.K.; Günther, C.C.; Kristensen, G.B.; Malinen, E.; Lyng, H. Combining imaging- and gene-based hypoxia biomarkers in cervical cancer improves prediction of chemoradiotherapy failure independent of intratumour heterogeneity. EbioMedicine 2020, 57, 102841. [CrossRef] [PubMed]

180. Bernauer, C.; Man, Y.K.S.; Chisholm, J.C.; Lepicard, E.Y.; Robinson, S.P.; Shipley, J.M. Hypoxia and its therapeutic possibilities in paediatric cancers. Br. J. Cancer. 2021, 124, 539-551. [CrossRef]

181. Strowitzki, M.J.; Ritter, A.S.; Kimmer, G.; Schneider, M. Hypoxia-adaptive pathways: A pharmacological target in fibrotic disease? Pharmacol. Res. 2019, 147, 104364. [CrossRef]

182. Haase, V.H. HIF-prolyl hydroxylases as therapeutic targets in erythropoiesis and iron metabolism. Hemodial. Int. 2017, 21, S110-S124. [CrossRef] [PubMed]

183. Seeley, T.W.; Sternlicht, M.D.; Klaus, S.J.; Neff, T.B.; Liu, D.Y. Induction of erythropoiesis by hypoxia-inducible factor prolyl hydroxylase inhibitors without promotion of tumor initiation, progression, or metastasis in a VEGF-sensitive model of spontaneous breast cancer. Hypoxia 2017, 5, 1-9. [CrossRef] [PubMed]

184. Graham, K.; Unger, E. Overcoming tumor hypoxia as a barrier to radiotherapy, chemotherapy and immunotherapy in cancer treatment. Int. J. Nanomed. 2018, 13, 6049-6058. [CrossRef] [PubMed] 